\title{
Sub-national deficits in European countries: The impact of fiscal rules and tax autonomy
}

\author{
Dirk Foremny*
}

November 29, 2013

\begin{abstract}
This paper empirically examines how fiscal rules and tax autonomy influence deficits of sub-national sectors across European countries. I use a new panel-data set to measure tax autonomy and the stringency of fiscal rules for EU15 regional and local government sectors over the period 1995 to 2008. I apply an instrumental variables approach to obtain an unbiased estimate of the impact of fiscal rules on deficits. I use political variables describing the central governments characteristics as instruments for fiscal rules at the sub-national level. The results show that the effectiveness of fiscal rules and tax autonomy depends on the constitutional structure. Fiscal rules decrease deficits only in unitary countries. Deficits of subnational sectors in federations can be avoided through tax autonomy.
\end{abstract}

Keywords: sub-national deficits, fiscal rules, soft budget constraints, fiscal federalism JEL Classification Numbers: H71, H74, E61

\footnotetext{
*Institut d'Economia de Barcelona and University of Barcelona, Spain, e-mail: foremny@ub.edu. I worked on this project when I was a PhD student at the University of Bonn. Financial support of the German Research Foundation is gratefully acknowledged by the author. Special thanks go to three anonymous referees, Juergen von Hagen. I also thank Steffen Osterloh, Momi Dahan, Jaime Luque, Amedeo Piolatto, Martin Stuermer, and other participants of the IIPF Annual Congress, EPCS Annual Meeting, the Lisbon Meeting on Institutions and Political Economy, the 2011 Workshop at the Universidade Portucalense, the Annual Meeting of the German Economic Association in Goettingen, and at the ZEW Workshop on Fiscal Performance: The Role of Institutions and Politicians in 2013 for helpful discussion.
} 


\section{Introduction}

The differences in the fiscal performance of sub-national governments across European countries are widely unexplored. The explanation of a sub-national bias towards deficits by institutional settings, such as fiscal rules and autonomy over tax instruments, is the utmost concern of the present paper. The empirical results explain why some countries are more affected by a deficit bias than others. Sub-national sectors in federations which have substantial autonomy over their tax instruments have lower deficits than those which have not. This paper also shows that only deficits in unitary countries can be avoided by tying the governments hands with fiscal rules, while they are ineffective in federations.

Since the early 1990's much attention has been devoted to explain why certain countries have experienced long periods of budget deficits that accumulated in high levels of public debt while others did not. The focus has been mainly on political and institutional factors, since even countries with similar underlying economic conditions showed a widespread variation in debt levels. The design of the institutions responsible for the budgetary process is considered one major determinant of the cross-country heterogeneity in fiscal positions (among others, see von Hagen and Harden, 1994, 1995; von Hagen, 2002, 2005; Alesina and Perotti, 1996, for this line of argument).

Most of the literature, both theoretical and empirical, focused on the central or general budget and national fiscal policy. Instead, the links between sub-national debts and deficits, their institutions, and in particular the restrictions imposed on them by fiscal rules, have not yet been explored in depth. The institutional background of the latter differs from the former because of the crucial role that vertical relationships play between different layers of government. This paper aims at investigating empirically the underlying forces from the perspective of sub-national jurisdictions.

The differences in fiscal positions below the national level can be caused by a deficit bias due to a common pool externality. Budgetary inflows may arise, to a certain extent, from a common source in the form of transfers or grants, while budgetary outflows are targeted to specific regions or municipalities. Often, sub-national entities have no direct influence over the instruments generating a substantial share of their revenues. von Hagen and Eichengreen (1996) introduced the idea of the local or regional tax base being responsible for bailout expectations and being connected, through this channel, to the deficit bias. Indeed in a dynamic context, they argue, budget constraints may become soft when governments are highly dependent on revenues that are not generated by their own instruments. Sub-national decision makers might expect, ex-ante, to be bailed out ex-post by a higher-level government if they cause a large and unsustainable deficit. In other words, the central government cannot credibly commit to a no-bailout policy, if the respective lower level governments have no power to solve fiscal problems on its own. Instead, when a large proportion of sub-national revenues comes from own tax resources, the central government may successfully persuade sub-national 
jurisdictions that, in case of excessive debt, they have to balance their budget by increasing tax rates under their control (von Hagen and Eichengreen, 1996).

A recent attempt to mitigate this time inconsistency problem of soft budget constraints was to impose fiscal rules on sub-national governments. The idea of fiscal rules is to force local or regional governments to act in the way the central level desires. The number of fiscal frameworks which impose balanced budget or debt rules on lower governmental sectors has substantially increased over the last two decades. The introduction of the Maastricht Treaty and the Stability and Growth Pact could be seen as the turning-point in the implementation of such rules applied to the sub-national sector.

As a first step, I analyze the reasons driving countries to adopt, keep, or strengthen their framework of rules. This is an important task that helps overcome a potential problem of endogeneity. Stricter rules may be adopted by governments with stronger preferences for fiscal discipline or a severe need for consolidation. The first case could create an omitted variable bias and the second case might create a problem of reversed causality. The first concern is usually addressed with fixed effects. I tackle the second identification problem by using political characteristics of the rule imposing level as instruments for the rules themselves at the lower governmental level. They fulfill the exclusion restriction since these political variables might have an impact on the fiscal outcome of the central level, but not on the deficits of sub-national governments.

I use a panel-data set of the sub-national sectors of the EU15 countries, covering data for fiscal rules, tax autonomy, and political and fiscal variables over the period 1995-2008. Regressions of the deficits of sub-national sectors on measurements of the strictness of rules and the discretion to tax show that the effectiveness of fiscal rules and the impact of tax autonomy depend crucially on the constitutional structure and division of powers. Fiscal rules work in unitary countries and not in federations. Implicit restrictions in the form of higher tax autonomy are an effective way to constrain excessive spending for the federal countries in my sample.

This paper is organized as follows: Section 2 motivates my research question by presenting stylized facts for sub-national public finances of the EU15 countries and presents the underlying theory and the related literature. Section 3 explains my identification strategy. Section 4 presents the data-set, and my results are presented and discussed in Section 5. Section 6 concludes. 


\section{Motivation and related literature}

\subsection{Stylized facts and theoretical background}

European countries differ substantially in the level of sub-national debt which they have accumulated in the past. Figure 1 shows the level of debt outstanding in 2008 as a share of GDP in the top panel.

[Figure 1 about here]

The figure shows that a substantial part of the total debt in European countries is due to sub-national borrowing. ${ }^{1}$ Most federal countries, and in particular Germany, show relatively large ratios of debt to GDP. However, this measure can be misleading, since it does not take into account the actual size of the sub-national sector. Therefore, the bottom panel depicts the outstanding debt as a share of revenues for the same year at the sub-national sector. Denominating fiscal variables in this way captures two important dimensions. First, it indicates the relevance of debt in terms of the capacity to generate budgetary inflows. Second, this measures the size of the sub-national sector as mentioned before. ${ }^{2}$ While the ranking for federal countries remains largely the same, this illustrates further the differences in unitary countries. Even though the Nordic countries have much larger sub-national sectors relative to the general government sector, their debt is lower compared to countries such as Portugal or France, which are less decentralized.

Since debts are (at least formally) ${ }^{3}$ the accumulation of deficits over time, the following questions arise. First, why did some federal countries, such as Germany, have on average larger deficits than other federal countries? And second, what drives the pattern of deficits over time in the unitary countries, even though the differences in decentralization have been taken into account? To sum it up, it is important to explore why sub-national sectors in some countries are exposed to a larger bias towards deficits than others.

A well-established reasoning for differences in debts and deficits at any level of government is that the respective decision makers do not fully internalize the costs of the public goods they acquire. This is known as the common pool problem of public budgeting. Since costs are shared by the whole population, theoretical models, as those of von Hagen and Harden (1995), Velasco (2000), Hallerberg, Strauch, and von Hagen (2009), and Krogstrup and Wyplosz (2010), emphasize that these costs are not fully internalized by the spending claims of individual spending ministers, in the sub-national context by members of local or regional councils. This results in overspending, since only a small part of the additional social costs of raising the tax

\footnotetext{
${ }^{1}$ The importance of the sub-national sector from the perspective of the general government also varies substantially. For example, the German sub-national sector accounts for almost $40 \%$ of total debt while for Greece this share is as little as $1 \%$.

${ }^{2}$ The actual size might be also depicted in terms of expenditures, but note that the ordering of countries does not change if I do so.

${ }^{3}$ See von Hagen and Wolff (2006) for a discussion of creative accounting and stock-flow adjustments.
} 
burden are taken into account, eventually creating a problem of $1 / n$. The more interest groups are involved in deciding the budget, the more fragmented the budget process becomes, and the larger the deficit bias due to individual spending claims. This is a result of a horizontal externality since it occurs within one government.

This point, which applies to every level of government, is supplemented by one that especially lets sub-national governments be inclined to overspend and borrow extensively. This occurs because several sub-national entities are grabbing for resources out of a national common pool (von Hagen, 2005). In this case the existence of soft budget constraints creates a vertical externality. Bordignon (2006) provides a survey of this literature. When a budget constraint is considered to be soft, a sub-national government can increase expenditures without facing the full additional social costs. A hard budget constraint instead makes the entity internalize the full additional social costs, since it expects to be responsible for the consequences of its spending plans (Rodden, Eskeland, and Litvack, 2003).

This problem is of a dynamic nature: sub-national governments can accumulate unsustainable debt levels if they expect ex-ante that the central government might wish to bail them out once fiscal obligations can no longer be fulfilled ex-post. In other words, sub-national governments might expect that under certain circumstances the central government will assume responsibility for the liabilities they accumulate. These expectations create a link between the future behavior of a higher-level government and the fiscal policy chosen at present. One main driving force of these expectations is intergovernmental fiscal transfers. The probability that a sub-national entity is not responsible for its fiscal decisions taken today is higher, the lower the share of own-source revenues is. In other words, the higher the dependency on central governmental grants and transfers, the higher the expectation of a bailout. This is because the central level has less room to ask for adjustments in sub-national taxes in the case of fiscal trouble, resulting in a dynamic game between the two governments (von Hagen and Eichengreen, 1996).

This "default-bailout game" between the central and sub-national level is formalized by Inman (2001) and Kornai, Maskin, and Roland (2003). The center commits itself at the first stage to a no-bailout policy. The sub-national level instead chooses to spend at a level where the local marginal benefit is higher than the marginal social costs if it has a strong belief that the commitment of the center during the first stage is not credible. Finally, the central government has to decide whether or not to provide additional transfers to the lower level in order to reduce the deficit there. If the center has strong incentives to do so, its actions will be anticipated by the lower level government. The budget constraint is the softer, the lower the costs of the center to provide additional funds compared to leaving the sub-national government alone with its deficits.

Starting with Wildasin (1997), several papers formalized the problem in partial equilibrium models in order to analyze the effects of different issues on the prevalence of soft budget con- 
straints (see Vigneault (2006) for an extensive overview of theoretical considerations). Wildasin (1997) focuses on the size and structure of jurisdictions. In his model the incentives of the central government to intervene in lower-level public finances is due to positive externalities of local public expenditures. Since these interventions can be anticipated at the first stage, local budget constraints are soft. The model of Goodspeed (2002) shows that a bailout forced by incentives of a lower level government to accumulate high debt has to be paid partially by other regions through increased taxation. Köthenbürger (2007) investigates the impact of fiscal equalization schemes, and Breuillé, Madiès, and Taugourdeau (2006) focus on the impact of horizontal and vertical tax competition.

In order to solve the soft budget problem of time inconsistent behavior, countries characterized by little revenue raising power at sub-national levels might impose more restrictions through fiscal rules on lower level governments in order to commit the local or regional level to fiscal discipline. Indeed, von Hagen and Eichengreen (1996) show that borrowing limits are more prevalent in countries where the share of sub-central government's own-source resources is small. This is because if own taxes could be adjusted, the central government could deny a bailout.

It has been also pointed out that these incentives might be different according to the federal organization of countries and the division of powers across governmental levels. For federal systems, Breuillé and Vigneault (2010) recently show that the soft budget problem can be worse in a multi-tier system if regional governments have discretion over transfer policies. In that case a soft budget constraint on the regional level yields even softer budget constraints on the local level.

The present paper aims at testing three hypothesis which have been derived from the theoretical literature discussed above.

H1 Higher autonomy over own tax resources mitigates the deficit bias which arises from a soft-budget problem.

H2 Fiscal rules can be an effective way to constrain sub-national sectors.

H3 The effect of the two mechanisms depends on the constitutional structure and differs between federations and unitary countries.

This paper provides an empirical analysis of all three hypothesis.

\subsection{Related empirical literature}

The theoretical interest in soft budget constraints in the context of fiscal federalism has also triggered empirical contributions in this area. Most existing studies focus either on crosscountry evidence over aggregated fiscal policy on the sub-national level, or country specific case 
studies. Rodden, Eskeland, and Litvack (2003) provide a collection of mostly descriptive case studies. Additional country specific evidence for sub-national bailouts is provided by von Hagen et al. (2000) for German states, Italian regions, and Australian and Swedish local jurisdictions. ${ }^{4}$ Evidence for Sweden is found by Dahlberg and von Hagen (2004). They show that the ability of the central Swedish government to commit to a no-bailout policy is rather weak, while the high degree of tax autonomy at the local level helps to harden budget constraints. A recent study by Pettersson-Lidbom (2010) identifies the expectations of local Swedish governments over a future discretionary grant by an instrumental variable approach. He uses the grants received by neighboring municipalities as an instrument for the anticipation of own additional future discretionary grants. A significant soft budget effect is found, and on average debt is increased by 20 percent when the budget constraint becomes soft. Apart from these studies, there is not much more empirical evidence at the country level. The lack of empirical work can be explained by the fact that expectations over the additional allocation of funds are not easy to measure, and as shown in the various case studies, numerous aspects of intergovernmental relations can create this effect.

Recent empirical work on fiscal rules at the general level of government across European countries $^{5}$ has established that their effectiveness depends on the institutional and political background of the respective country. Evidence in von Hagen (2006) underpins the importance of the design of the budget process that enables the government to commit to the rule. Hallerberg, Strauch, and von Hagen (2007) show that the stringency of fiscal targets has an impact in European countries which are characterized by ideological dispersion in the government. An intensive discussion of these results is provided in Hallerberg, Strauch, and von Hagen (2009). Similar results are obtained by the study of Debrun et al. (2008), who apply another indicator to capture the strictness of rules across European Union countries.

Empirical contributions that are closely related to this paper perform cross-country comparisons at the sub-national level. ${ }^{6}$ This literature focuses on the differences across countries in order to investigate which institutional elements have an impact on sub-national fiscal policy. Rodden (2002, 2006) uses a panel-data set of forty-three OECD, developing, and developed countries over ten years (1986 to 1996). A first set of results is based on ten-year average regressions, capturing long-run effects. He finds that vertical fiscal imbalance (here the share

\footnotetext{
${ }^{4}$ Among others, further contributions deal with bailouts across the German states (Seitz, 2000; Fink and Stratmann, 2011; Baskaran, 2012), Spanish regions (Sorribas-Navarro, 2011), and various Latin American countries (e.g. Echavarria, Renteria, and Steiner, 2002; Bevilaqua, 2002; Nicolini et al., 2002).

${ }^{5}$ For studies exploiting variation across US states see, among others, von Hagen (1991); Poterba (1994); Bayoumi and Eichengreen (1995); Poterba (1996); Fatás and Mihov (2006). Bohn and Inman (1996) find that only constitutional rules prevent deficits in US states, while statutory ones do not. Feld and Kirchgassner (2006) find that across Swiss cantons those with fiscal constraints have significantly lower deficits. In addition, Alesina et al. (1999) show for a sample of Latin American countries that well designed budget institutions reduce deficits.

${ }^{6}$ Another strand of literature deals with the overall effect of decentralization. Baskaran (2011) provides an excellent overview.
} 
of grants and shared taxes in revenues) is positively related to deficits. For a second set of results all countries are grouped in two categories, countries with high and low borrowing autonomy. For the high-autonomy group he finds that vertical fiscal imbalance is still a driving force of deficits, while there is no effect for the countries with low borrowing autonomy. As mentioned in the conclusion of that paper, more work should be done to investigate the effects of tax autonomy, and in particular the changes over time and the different degrees of borrowing autonomy. Plekhanov and Singh (2007) analyze with a panel-data set over 1982-2000 which specific institutional design of borrowing constraints prevents large sub-national deficits. Their classification of fiscal rules is based on dummies according to the way the rules are imposed. This paper finds, while averaging over all years for each country, that rules imposed by the central government and cooperative agreements reduce deficits when the vertical imbalance is large. So far, the constitutional structure of countries has not been taken into account. Recently, Foremny and von Hagen (2013a,b) have analyzed the adjustment behavior of subnational sectors to negative revenue shocks and find important differences between unitary and federal countries.

These days almost all European sub-national governments are constrained by some fiscal restrictions. The classification into categories as in Plekhanov and Singh (2007) is not without ambiguity. Another shortcoming of the existing empirical literature is that none of the papers provide a panel analysis which accounts for the changes in fiscal rules and tax autonomy over time. This is because time invariant indicators are used, and institutional changes are neglected; or because some results are based on between estimations, which were carried out on the average of the variables per country over time. Fiscal rules differ over time and how stringent and transparent they are applied. In particular European countries introduced numerous rules for sub-national sectors over the last two decades. I use a continuous index, rather than a categorical approach, to investigate whether the strictness of rules has an impact.

Similar arguments apply to the characterization of own-source revenues. The concept of vertical fiscal imbalance should be taken into account carefully, since sometimes it has not been considered that shared taxes are eventually not very different from grants. Tax rates cannot be decided individually at the sub-national level. To improve on this, I focus on the development of own-source taxes. This takes into account the distortionary nature of taxes, when central governments ask for adjustments by increasing tax rates rather than providing additional funds through bailouts or by increasing grants. This is even more important since the underlying problem of soft budget constraints is a dynamic one. Solving these issues is one of the main contributions of this paper. I estimate panel models where I carefully construct measures of the tax autonomy of sub-national sectors, the different strength of borrowing restrictions in the form of fiscal rules, and explicitly take into account the variation over time. This can be interpreted as comparing the outcome for times before major reforms of rules and tax autonomy were implemented with the time after their implementation. 
A further well known problem in the literature on fiscal rules is that their correlation with deficits does not necessarily have to be causal. Studies on the national level have highlighted the lack of good quality instruments in order to address a problem of endogeneity. The explicit sub-national context instead allows finding variables that are correlated with the fiscal rules index, but are orthogonal to the error term. I exploit the fact that fiscal rules in the EU15 are in almost all cases imposed by a higher level of government. Earlier contributions have shown that political economy variables are able to explain the stringency of fiscal rules (see Debrun et al. (2008), for instance). However, on the national level these variables might not be simultaneously uncorrelated with budgetary outcomes. In the case of sub-national sectors instead the decision makers over rules (the central government) and the decision makers over budgetary policy (the sub-national entities) are not the same. I will make use of the fact that the characteristics of central governments, which impose rules on the sub-national one, are unlikely to be correlated with their budgetary outcomes, but describe well the prevalence of rules. My identification approach is described in the next section.

\section{Identification}

The main objective of this paper is to analyze if the budgetary position can be explained by autonomy over taxation and fiscal rules. I estimate a reduced form model of a fiscal reaction function according to equation (1):

$$
D_{i, t}=\boldsymbol{\gamma} \boldsymbol{\Phi}^{\prime} \text { tax }_{i, t-1}+\boldsymbol{\delta} \boldsymbol{\Phi}^{\prime} \text { rules }_{i, t}+\boldsymbol{\beta} \mathbf{X}_{\mathbf{i}, \mathbf{t}}+\mu_{i}+\eta_{t}+\varepsilon_{i, t}
$$

The dependent variable is a measure of the budget deficit, $D_{i, t}$, at the sub-national level. The impact of the tax-structure in terms of sub-national autonomy is captured by the parameter $\gamma$. A negative and significant effect would confirm hypothesis $H 1$. I estimate the reaction to a lagged variable of the share of taxes which are under discretion of the respective government. Using the one period lag is important since policy makers will use their information from the past to build their expectations about the future. A high dependency on own-source taxes in the past indicates that it is likely that current deficits must be paid back by own resources instead of expecting to receive transfers from the central government. The parameter $\delta$ captures the impact of fiscal rules, and a negative and significant effect would confirm $H 2$. The data section explains in detail how the variables tax and rules are constructed.

The impact of other control variables is measured by the parameters in the vector $\boldsymbol{\beta}$. $\mu_{i}$ and $\eta_{t}$ are individual and time fixed effects. The inclusion of individual fixed effects is, besides capturing unobserved heterogeneity, important to focus on the dynamic nature of the underlying problem. I aim at an estimate of the impact of changes in the institutional framework on budgetary outcomes in the form of annual deficits. Hence, the question is how rules and 
autonomy affect deficits in the short run, and the fixed effects capture all time invariant factors, including preferences for sound fiscal policy.

It is important to take the connection of the sub-national level to the higher level of government into account. The mechanism to tie the hands of lower-level governments by granting more autonomy might work in federations, where lower-level governments have substantial degrees of freedom over their policies and legal acts. On the contrary, in unitary countries the sub-national level sometimes can be seen as an extension of central government policies. When the sub-national level is not much more than a branch of the central one, a credible commitment of the center to a no-bailout strategy might be impossible in any case (even in line with a positive impact of autonomy on deficits). To capture these effects, the two main variables of interest in Equation 1 are interacted with a set of dummy variables:

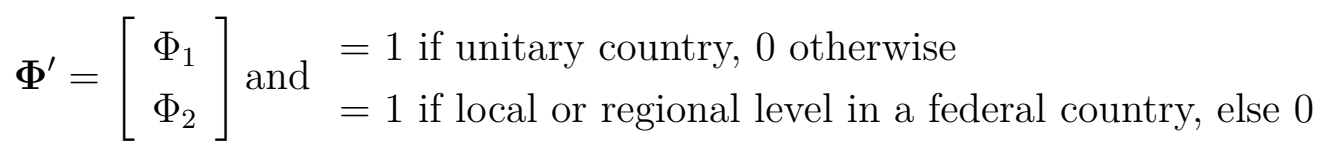

The dummy variables classify the respective form of government. ${ }^{7}$ Doing so allows to estimate separate coefficients on tax autonomy and fiscal rules for federal and unitary countries. If slopes turn out to be different, hypothesis $H 3$ will be confirmed.

The possibility that fiscal rules are the result of, rather than the reason for fiscal performance, requires a careful analysis of causality. I use an instrumental variable approach to overcome this hurdle. I estimate the factors determining the fiscal rules index. I include political determinants of the level of government which is implementing the rules, indicators of the general fiscal stance of the respective country, as well as dummies for different time periods (the time of the Stability and Growth Pact, for instance) and further controls, included in $\mathbf{Z}$, into the model.

First, as shown in Equation (2), I estimate a model for each value of the fiscal rules index $j$ across countries, using the average of covariates during the time span when the rule was in force:

$$
\text { rules }_{j}=\gamma \overline{\text { pol }_{\mathbf{j}}}+\delta \overline{\text { budget }_{\mathbf{j}}}+\boldsymbol{\theta} \overline{\text { time }_{\mathbf{j}}}+\beta \overline{\mathbf{Z}_{\mathbf{j}}}+\varepsilon_{j}
$$

Second, I estimate conventional fixed effects models to capture the variance in rules over time according to the model in Equation (3):

$$
\text { rules }_{i, t}=\gamma \mathbf{p o l}_{\mathbf{i}, \mathbf{t}}+\boldsymbol{\delta}_{\mathbf{b u d g e t}_{\mathbf{i}, \mathbf{t}}}+\boldsymbol{\theta} \mathbf{t i m e}_{\mathbf{i}, \mathbf{t}}+\boldsymbol{\beta} \mathbf{Z}_{\mathbf{i}, \mathbf{t}}+\mu_{i}+\varepsilon_{i, t}
$$

Ideally, this step offers candidates for instruments which I can use for an unbiased estimation of the impact of fiscal rules on budgetary outcomes. I re-estimate Equation (1) and use the variables which are found to be correlated with the rules index to instrument this variable in

\footnotetext{
${ }^{7}$ Austria, Belgium, Germany, and Spain are treated as federations. Please refer to Table 7 in the Appendix A for details of the classification.
} 
equation (1). I report results from 2-stage least-squares estimations but I also apply DifferenceGMM (i.e. Arellano and Bond, 1991) in order to estimate dynamic models including a lagged dependent variable among the regressors.

This identification procedure corrects some drawbacks of former empirical approaches. First, the focus on the within variance with time-varying indicators allows identification of the effects in the short run. Second, including the lagged value of tax autonomy creates a better reflection that decision makers form their expectations by observed values from the previous period. Last, the proper choice of instruments can eliminate a potential problem of reversed causality.

\section{Data}

This study is using aggregate data for sub-national sectors. All EU15 members are included over a period ranging from 1995 to $2008 .{ }^{8}$ I include regional and local governments as separate entities for four federal organized member states. This provides 19 observations per year and 266 in total over the fourteen years covered by my data set. ${ }^{9}$

\subsection{Dependent variable and indicators of fiscal rules and tax autonomy}

The dependent variable is a measure of the budgetary position in each year. I use annual deficits, either denominated by GDP or by sub-national total revenues as the main dependent variables. Defining the dependent variable as share of revenues measures differences in capabilities to raise government income and relates the size of deficits to the actual capacity of the sub-national sector. This is the relevant measure from the perspective of a sub-national entity and has been used in the previous literature. A measure denominated by GDP is appropriate for a general government perspective. I report results for both variables for comparison.

Two indicators have to be computed to investigate the effects of fiscal rules and tax autonomy. I construct both indicators as a time-varying index that captures the development for each country over the entire time period.

First, an indicator of tax autonomy is needed to test whether the dependency on own tax resources creates incentives to balance the books. I compute an indicator of the share of own-source tax revenues in total revenues at each governmental level. The classification of

\footnotetext{
${ }^{8}$ The choice of this period is mostly the result of data restrictions as years prior to 1995 are not available and more recent years are often subject to revision by EUROSTAT. Furthermore, some data for the IV strategy is not available after 2008. However, in Foremny and von Hagen (2013b) we focus on the cyclicality of subnational rules and expand the sample up to 2010. We cannot apply the IV strategy due to the above-mentioned data limitations. That paper re-estimates the baseline model by OLS for comparison. Results for the sample including two more years remain unchanged.

${ }^{9}$ Please refer to Appendix D for robustness checks on alternative sample designs. Main results remain unchanged.
} 
own-source revenues is, unfortunately, not straightforward. Other studies rely on the degree of vertical imbalance or the share of taxes in total revenues, which can be misleading. ${ }^{10}$ It is important to distinguish real own-source revenues from those revenues arising due to taxsharing arrangements, i.e. taxes collected by a higher level and automatically transferred to the lower one. The OECD (1999) provides a classification of the taxing power of sub-national levels. Unfortunately, their Fiscal Decentralization Database provides only information for two or at most three years, 1995, 2002, and 2005. I use the Revenue Statistics of the OECD, the Taxes in Europe database of the European Commission, numerous national sources over changes in tax-systems, and the information provided by Stegarescu (2005) to construct a comparable indicator over the entire 14 years of the sample. I treat all taxes over which either discretion on rates, reliefs, or both are under the power of the sub-national entity as own-source tax revenues. This measure does not overestimate the revenue autonomy in the presence of shared taxes.

[Figure 2 about here]

Figure 2 provides a graphical representation of this indicator. The Nordic countries are characterized by the largest share of autonomous revenues while German states, both Austrian sectors, Ireland, and the Netherlands have on average very little discretion over their revenues. Variation in the indicator is generated by two different effects. On the one hand, the taxsystem can be changed, equipping lower level governments with a richer set of instruments or more autonomy over existing taxes. Some governmental sectors, such as the Spanish regions and the sub-national Italian sector have implemented considerable changes within this period. On the other hand, the share of other revenues could also shift when the center re-allocates resources to lower levels of government. A value of zero indicates that all available revenues are either grants or transfers from other levels of government while a value of 1 indicates that the sub-national sector has full discretion over taxes which cover all their revenues. An increasing value of this indicator represents a lower dependency on transfers at the sub-national level and, according to $H 1$, might help to avoid soft budget constraints.

Second, I construct another indicator to depict the strength of fiscal rules, i.e. how stringent borrowing is regulated. Fiscal rules are nowadays frequently used at the sub-national level in European countries (European Commission, 2009, 2008, 2006; Sutherland, Price, and Joumard, 2005) to mitigate a deficit bias and to harden the budget constraint by imposing numerical targets on budgetary variables or limiting the access to credits. I use the data provided by the European Commission (2009) to create an index of the strictness of rules. All fiscal rules which have an impact on the fiscal balance are included in the calculation of the index: balancedbudget-rules, debt brakes, and other direct restrictions on borrowing. ${ }^{11}$ The original EU index

\footnotetext{
${ }^{10} \mathrm{~A}$ good example are German federal states. Their share of tax revenues in total revenues is substantial, but the share of real own-source taxes is close to zero since they cannot decide on an individual tax rate.

${ }^{11}$ Expenditure ceilings are very rare at the sub-national level and, as in the original EU variable, excluded
} 
is adjusted to the situation of sub-national levels. In the non-federal countries, an average of the rules applying to different levels, weighted by their share of expenditures in the total sub-national budget, is used. The indicator is forced to vary between 0 (in the case if no fiscal rule is applied) and 1 (in the case of the strictest rule during the period). ${ }^{12}$

[Figure 3 about here]

Figure 3 shows the development of this indicator. The restrictions are relatively stable over time in one group of countries (Belgium, Germany, Denmark, France, and Finland) while another group (Austria, Spain, Ireland, Italy, Portugal, and Sweden) has increased the strictness of rules in recent years. Most countries introduced national stability pacts as an answer to the limitations arising from European supranational rules. ${ }^{13}$ A third group (Greece, Luxemburg, The Netherlands, and The United Kingdom) goes without strict rules. When these fiscal arrangements work as an effective tool to dampen a deficit bias, a negative coefficient is expected.

\subsection{Control variables}

The other controls are summarized in Table 1. The fiscal position of the central government def_cg_rev is included to capture a copycat effect. Sub-national governments that observe a loose fiscal policy at the national level can follow the example given by the central government, expecting that they are not sanctioned if the higher level is profligate as well.

[Table 1 about here]

The degree of decentralization is taken into account by the share of sub-national expenditures in general government expenditures edec. Unfortunately, this indicator is not able to distinguish between expenditures that could be categorized as compulsory or those that are optional to provide. Nevertheless, the share of expenditures captures the weight of the sub-national sector in the general budget and how spending proportions are shared between the governmental levels. These shares differ across European countries, with varying responsibilities and discretion over their exercises.

[Figure 4 about here]

Figure 4 shows the country means over my period of study. The Nordic countries are characterized by a high level of services and responsibilities on the local level. Danish sub-national governments spend on average more than every second Danske kroner, followed by their Swedish and Finnish neighbors. The regional levels of Belgium, Spain, and Germany are responsible

for the main analysis of the impact of rules on deficits.

${ }^{12}$ The construction of this index is described in detail in Appendix C.

${ }^{13}$ For example, the change in the rule index in 2001 in Austria is due to the Oesterreichischer Stabilitaetspakt and the change in the same year in Italy can be explained by the Patto di stabilitá interno. 
for approximately one quarter of total expenditures, accompanied by their local governments with additional, but lower expenditure shares. The less decentralized countries are France, Portugal, Luxembourg, and Greece. The plot against the average of own-source tax revenues indicates that in many cases higher expenditure decentralization is accompanied by a higher degree of autonomy over tax revenues. As noted before, this is not the case for some countries, in particular not for the German federal states and for Austria, Ireland, and the Netherlands.

Additional covariates are included to capture cyclical and institutional effects and to consider the spending needs of lower-level governments. I include the output gap outgap, the unemployment rate unempl, the ratio of the working age to total population depratio, and interest expenses intexp_rev. All fiscal variables are computed as shares of revenues. Population $I_{\text {population }}$ enters in logs and is denominated by the maximum value of the sample to facilitate interpretation (see Neyapti (2010) for a similar transformation).

\subsection{Political variables}

Whereas national fiscal rules are often self imposed, nation-wide rules for sub-national sectors are not. Usually they are imposed by the central level, and institutional and political variables of that level have an impact on the strictness of the rules which are implemented over time. Even though one can argue that in federal countries the regional level could impose rules on the local one, this has not been observed over the last decades. The new fiscal frameworks in Spain and Austria for instance were both imposed on all sub-national levels by the central government. $^{14}$

Table 2 summarizes the political variables, which I take into account for the estimation of fiscal rules themselves. The motivation for the central government to impose restrictions on lower level governments could be determined by the perception that a soft budget problem is at hand. Thus, the federal structure itself plays a role and several determinants of the deficit might also be crucial for the strictness of rules. These issues are taken into account by using some of the variables already discussed. This, being interesting by itself, would unfortunately not provide valid instruments as those variables have to be included directly in the deficit estimation. However, the central level itself must also believe that fiscal rules are a mean to cure the problem and must be able to implement the rules through the legislature. Political variables which characterize the central government and its preferences might be related to fiscal rules. Most of the data is obtained from the World Bank Database of Political Institutions 2009 (Beck et al., 2001).

\footnotetext{
${ }^{14}$ Self-imposed rules of particular regional governments and their local counterparts are a somewhat new phenomenon. The sample in this paper covers data up to 2008, and none of the rules taken into account are self imposed by a regional level or imposed by that level on the local government sector. However, some regions or cities may have additional self-imposed restrictions. As data is aggregated for sub-national sectors, this is not explicitly taken into account in my analysis. This issue has been recently addressed by Brooks, Halberstam, and Phillips (2013) but is beyond the scope of the present paper.
} 
[Table 2 about here]

First, to control if the ideological orientation of the government plays a role, an index over the two main government parties, reaching from zero (left-wing, single party government) to one (right-wing, single party government), is calculated. There is no general conjecture over the direction of the impact of this variable, and the sign could point in either direction. ${ }^{15}$

Second, the Herfindahl index measures the fractionalization of the ruling coalition. A single party government yields a value of one, while values close to zero indicate a more dispersed government. The index can be interpreted as the probability that two randomly picked members of the ruling coalition belong to the same party. The expected sign of this variable is not clear. On the one hand, a more fragmented government could be willing to restrict lower levels, because they are able to blame other coalition members when local or regional politicians complain about new rules. On the other hand, a less fragmented government might find it easier to pass new rules through the legislature.

Third, the district magnitude measures the average number of seats in the parliament per electoral district. Beside the impact on the effective number of parties, ${ }^{16}$ the district magnitude might have an additional impact in the sub-national context. A higher value indicates that more seats are allocated within one electoral district. Hence, the connection between local politics and the politicians elected into the central parliament might be loose. On the contrary, a small district magnitude means that the representative in the central legislature could be seen as directly responsible for the respective district. A strong connection to the sub-national level might cause representatives to be cautious with imposing strict rules, because they do not want to cross with local politicians and voters.

Last, I include the predicted form of fiscal governance, according to von Hagen and Harden (1995), Hallerberg, Strauch, and von Hagen (2007), and Hallerberg, Strauch, and von Hagen (2009). This literature characterizes whether a delegation or contract approach of fiscal governance is appropriate for different countries. Centralizing the budget process could be done by the former approach by delegating authority to one member of the executive that is vested with special strategic power. On the national level the finance minister is typically in charge of this special function. The contract approach instead relies on agreements between all members of the cabinet with spending rights. I include the indicator developed in this literature to investigate whether central governments that are assumed to be contract countries follow this approach when designing rules for sub-national levels.

Conditional on the results some of these variables could be used to instrument the fiscal rules index as they do not have to be included into the deficit estimation itself (they fulfill the exclusion restriction) but may explain the strictness of the fiscal framework (are highly

\footnotetext{
${ }^{15}$ Debrun et al. (2008) report evidence that more conservative orientated governments make less use of fiscal rules.

${ }^{16}$ The idea was developed by Duverger (1954), tested empirically by Taagepera and Shugart (1993) and put in the context of budgetary politics by Hallerberg and von Hagen (1999).
} 
correlated with fiscal rules).

\section{Results}

\subsection{The political economy of sub-national fiscal rules}

This section explores which factors induce a higher reliance on rules, and which circumstances trigger the adoption of rules. ${ }^{17}$

[Table 3 about here]

The first column of Table 3 presents the results from an OLS regression according to Equation (2) of each single outcome of the fiscal rules index on the average values over the period in which one set of rules was in force in a given country. ${ }^{18}$ In other words, each value of the fiscal rules index appearing in a country is regressed on the average values of all other covariates during that time. This simple approach reveals interesting insights, at which I look with more sophisticated methods according to Equation (3) in columns (b) to (d). The first two remaining models (b and c) provide evidence from a pooled model, and the last (d) shows results from a fixed effect estimation. Model (c) includes the lagged value of the rules index to account for the persistence of this variable.

The top panel of the table shows the impact of political variables on the rules index. The first variable her fgov is significant and negative in almost all specifications, except the dynamic one in model (c). A government which consists of a single party or of one big and one small coalition member, represented by a higher value of the Herfindahl fractionalization index (i.e. a less fractionalized one), tends to impose less strict rules. One-party governments might receive more leeway from their sub-national counterparts and might try to avoid this conflict. Countries that are supposed to follow a contract approach of fiscal governance at the central level (Hallerberg, Strauch, and von Hagen, 2009) impose less strict rules on their sub-national governments. The district magnitude also becomes significant and positive in the panel specification. ${ }^{19}$ This supports the view that rather loose connections to lower level politics increase the use of fiscal rules at the sub-national level.

None of the other political variables, and neither budgetary ones, have an impact on the rules themselves. It is important to note that this implies that sub-national deficits do not have a feedback effect on rules. The only budgetary variable which is significant in at least

\footnotetext{
${ }^{17}$ The hurried reader who is only interested in the results for budgetary outcomes can skip this section and continue in Section 5.2

${ }^{18}$ The interpretation of dummies that vary over time such as elections or the stability and growth pact are in this estimation an indicator over the relative number of events in the respective time span. For example, sgp takes the value 0.6 if the rules was valid during 6 years of the Stability and Growth Pact.

${ }^{19}$ Due to the little within variance, I check whether this result is robust when I include time dummies. The parameter is still significant at the same level.
} 
one specification is the lagged debt level of the general government in the panel specification (d). Central governments impose restrictions when general fiscal stress is at hand, but do not react to deficits at the sub-national level.

In terms of timing, the introduction of the Stability and Growth Pact has (from 1999 onwards) increased the strength of rules. This effect is not surprising since most national stability pacts were introduced as an answer to the supranational European fiscal framework in order to force the lower level governments not to counteract central level fiscal policies. Also not surprising is that rules increase over time, as indicated by the included linear trend. Out of the other control variables only the demographic structure, the population size, the sub-national tax autonomy, and unemployment have an increasing impact on the implementation of fiscal rules.

To sum up, the fractionalization of the government in power, the district magnitude, and the predicted form of fiscal governance determine the strictness of sub-national fiscal rules. Ideology of the central government and national elections instead do not. Neither do the budgetary variables, beside the lagged overall level of debt, as long as a static model is estimated. However, constituencies in federal countries, as indicated by the two dummies against the base group of unitary countries ${ }^{20}$, rely more on rules than their non federal counterparts. This indicates that the political actions of the center to implement rules in unitary and federal countries might be different. In particular, the timing when the center implements rules, and whether the present or lagged political variables matter, may differ as the ultimate results have suggested.

[Table 4 about here]

The estimations presented in Table 4 show that this is indeed the case. Model (a) to (e) include separate coefficients for federations and unitary states as well as their one period lag for one of the political variables per estimated equation. For example, column (a) shows a regression with four different coefficients for the impact of the Herfindahl index on rules: the current value of federal countries, the lagged value of federal countries, the current value of unitary countries, and finally the lagged value for this group. Models (b) to (e) continue with this procedure for the other covariates. Column (f) shows the estimates of the full model, including lagged and current values of all variables simultaneously.

Model (a) shows that it is rather the one period lag than the current value of the Herfindahl index which matters. Furthermore, it can be seen that federal countries do not follow the direction described above. In this case there is a positive relationship, indicating that less fractionalization is associated with stricter rules. In federal countries the central government might impose those stricter rules in order to tie the hands of sub-national politicians, which might belong to a different party. An ideological position of central governments which is contrary to the majority of sub-national ones is a frequently observed feature in federal countries.

\footnotetext{
${ }^{20}$ Note that this variable is omitted in the panel model as it is time invariant.
} 
Surprisingly ideology is now marginal significant at the $90 \%$ level for unitary countries when the lags of all variables are included in the model as shown in (f). Election year effects (b) instead are still not observable. As for fractionalization, also the district magnitude seems to be more important one period lagged for unitary countries, but according to estimation (d) and (f) signs do not change. A higher value of this variable is still increasing the rules index. The contract approach in central governments' fiscal policy instead is different for both types of countries with respect to the timing. For the federal ones the actual one is significant and negative, while for the unitary states the one period lagged value matters.

\subsection{The impact of fiscal rules and tax autonomy on deficits}

\subsubsection{Baseline estimations}

Table 5 presents the results of the regressions for budgetary outcomes. The dependent variable in any model included in this table is defined as the annual sub-national deficit as a share of of GDP. Positive values arise if expenditures exceed revenues and all coefficients with a negative sign improve the budget balance by reducing deficits. All models include fixed effects at the observational and year level. Including fixed effects is important in this context to exploit the variation within groups over time and to capture time-invariant preferences for fiscal sustainability. In addition, an F-test $\left(F_{(18,216)}=6.36\right.$, p-value 0.00$)$ indicates that significant individual effects are at present and pooled estimations are not efficient. Baltagi (2005) test of poolability rejects the null of excluding fixed effects. $\left(\operatorname{LR} \chi_{(20)}^{2}=114.90 \text {, p-value }=0.00\right)^{21}$

[Table 5 about here]

The first column (a) shows results from panel regressions according to Equation (1) which does not distinguish between unitary and federal countries. I find no significant effects of the strength of fiscal rules when I do not allow for different slopes for federations and unitary countries. Lagged tax autonomy turns out to be significant and negative in this model. A Baltagi (2005) test of the poolability ${ }^{22}$ of the two groups and the estimation of one slope parameter only clearly rejects $\left(\operatorname{LR} \chi_{(2)}^{2}=11.39, \mathrm{p}\right.$-value $\left.=0.00\right)$ this model against the alternative specification with different slopes as in models (b) to (d). ${ }^{23}$ This is a first confirmation of hypothesis $H 3$.

The remaining models take account of this by allowing for different slopes. The results of model (b) reveal that the impact of tax autonomy is limited to federal countries (i.e. $H 1$ can be verified for this group). At the same time fiscal rules turn out significant in unitary

\footnotetext{
${ }^{21}$ A Hausman test rejects the appropriateness of a random effects model $\left(\chi_{(12)}^{2}=39.00\right.$, p-value $\left.=0.02\right)$

${ }^{22}$ I thank the anonymous referee for suggesting to test for poolability.

${ }^{23} \mathrm{~A}$ similar test confirms this specification and rejects a model which also differentiates between local and regional levels of federations $\left(\mathrm{LR} \chi_{(2)}^{2}=1.33\right.$, p-value $\left.=0.51\right)$. Please note that this differentiation cannot be made in unitary countries as only data for the entire sub-national sector is available.
} 
countries (i.e. $H 2$ can be verified for this group). According to the hypothesis of soft budget constraints, sub-national governments in federations run lower deficits when their share of ownsource tax revenues in the previous year has been a relatively large share of total sub-national revenues. Given an increase in the share of revenues directly at their hands, it is perceived that these own generated revenues also have to be used for potential future liabilities, causing lower present deficits. Sub-national sectors in unitary countries instead show up with an opposing behavior. These governments might anticipate that they are more or less the extension of the central government and giving them more autonomy does not constrain them sufficiently from profligate spending. Results are different for sub-national sectors of unitary countries. They can be constrained by stricter fiscal rules: according to model (b) of Table 5 they overspend less when fiscal rules are stricter and the access to borrowing is limited. In this case, fiscal rules are an effective tool to mitigate a deficit bias, although tax autonomy is not. This does not hold true for federally organized states, where in no specification a significant coefficient is detected.

\subsubsection{Instrumental variables estimations and Dynamic GMM}

The previous estimates might be biased as fiscal rules could be endogenous. In what follows I use an instrumental variables approach to achieve unbiased estimation results. To do so, variables that satisfy the two properties of valid instruments, namely being uncorrelated with the error of the regression of Equation (1), but highly correlated with the rules index, must be found. This is usually regarded as a complicated task: explanations for the prevalence of fiscal institutions, for instance political variables which reflect preferences, might be simultaneously connected to the result of fiscal policy. This would imply that they are correlated with the variable that captures fiscal rules, but also with the error term.

The context of sub-national budgetary outcomes instead offers a convenient feature to tackle this hurdle. Rules and institutions for lower level governments are introduced by a higher level of government. The characteristics that drive the introduction of the rules, as worked out in Section 5.1, are correlated with the rules itself (and might be correlated with the budgetary outcomes of that higher governmental level), but not with the budgetary position of the governments where the rules are imposed on. The previous section has shown that political characteristics of the central government are indeed related to the strictness of rules. In addition, there was no feedback effect of deficits, which excludes that central governments introduce rules when sub-national deficits are regarded as unsustainable. Hence, there are possible candidates for a set of instruments which are correlated with the endogenous fiscal rules variables, but are not correlated with the error term in the explanatory equation. In other words, those variables are in line with the exclusion restriction in instrumental variable regressions. While including fixed effects might sufficiently control for preferences for sound fiscal policy (see Iara and Wolff (2011) for a discussion of this), this IV strategy ensures that 
there is no issue of reversed causality.

I use the variables which are, according to the previous section, found to be correlated with the fiscal rules index as instruments. These are current values and the one-period lag of the interacted district magnitude, the form of fiscal governance, and the Herfindahl index of government fractionalization. ${ }^{24}$ The results of a two-sage least squares regression are reported as model (c) of Table $5 .{ }^{25}$ Specification tests confirm this model choice as a Hansen-test rejects overidentification and the Kleibergen-Paap F-Statistic rejects weak identification.

The absolute value of the coefficient on fiscal rules in unitary countries is now approximately more than twice as large as before. This indicates that the earlier estimate was biased towards zero. In terms of significance both models make the same predictions, and surprisingly also tax autonomy in unitary countries is gaining significance. The positive coefficient, however, indicates that higher autonomy in this group of countries does not work as a limitation but rather as an augmentation for deficits. This effects vanishes when I estimate the model by GMM including the one period lag of the dependent variable. This model $(d)$ confirms the baseline results for tax autonomy and fiscal rules, as the former is still significant for the federations in the sample and the latter for the group of unitary countries.

The other significant covariates are in line with expectations. Countries that are more decentralized in terms of expenditure shares run on average higher deficits. Demographic changes reveal two interesting insights. First, when the total population grows, so do deficits. Local services are often connected to the number of people that call for them; hence more people represent larger spending needs. Second, when the share of the working population grows in terms of the dependency ratio, budgetary positions improve. All other variables do not have an impact on deficits which is significantly different from zero in any model.

\subsubsection{Discussion}

From the perspective of the sub-national sector the deficit as a share of revenues or in percapita values might be a more relevant indicator than the share of GDP. For example, the Spanish fiscal rule is defined in this way as the level of accumulated short run debt has to be below $15 \%$ of current revenues of the previous fiscal year. Table 6 repeats the static IV and dynamic GMM estimation with deficits as a share of sub-national revenues or per-capita deficits as dependent variables. The share of sub-national revenues (or expenditures) has been used previously in this line of research ${ }^{26}$ as this measure relates the deficit to sub-national financial capacities.

\footnotetext{
${ }^{24} \mathrm{~A}$ detailed analysis of the choice of instruments can be found in the working paper version of this paper available as Foremny (2011). Note that none of the performed robustness checks in that version of the paper generated results different from those I present in the present paper.

${ }^{25}$ I report the first stage estimations for this regression in Appendix B.

${ }^{26}$ Among others, e.g. Rodden (2002); Rodden, Eskeland, and Litvack (2003); Plekhanov and Singh (2007). See Eichler and Hofmann (2013) for an overview of specifications.
} 
[Table 3 about here]

The results for deficits as a share of revenues are in line with those of Rodden (2002) and Plekhanov and Singh (2007) and confirm the results from the previous section. More autonomy over revenues generated by own-source taxation is an implicit tool to constraint sub-national governments in federal organized countries. Interestingly, per-capita deficits to do not react to fiscal rules in the dynamic specification. In the sense of an placebo test this confirms the appropriateness of the fiscal rules indicator as rules usually don't define the targets which have to be met in per-capita terms.

These results are encouraging for policy makers. Figure 5 depicts the marginal effect of stricter rules in unitary countries in the top panel (a) and the effect of tax autonomy in federations in the bottom panel (b). The bars on the left show the actual value of the fiscal rules index and tax autonomy in the year 2008 across countries. Significant improvements of budgetary positions are potentially feasible through reforms of rule frameworks and the structure of tax systems. This is particularly true for countries which currently make little use of those mechanisms. If, for example, the UK would reach the value of the Irish rules index the annual share of deficits in revenues could on average be reduced by 2.7 percent, ceteris paribus. Some countries also would substantially benefit from more tax autonomy. The lower panel shows that if German states would have similar taxing power than Spanish regions, the model would predict a reduction of 7.5 percent of deficits, ceteris paribus. As a central policy recommendation, reforms of the institutional framework can reduce deficits if implemented in the right way.

A last open question is if these two instruments work in isolation or if there is an interplay between the two. To check for this, I re-estimate the model and allow for interaction between the fiscal rules index and tax autonomy. ${ }^{27}$

[Figure 6 about here]

The top panel (a) in Figure 6 shows a plot of the marginal effect of fiscal rules in unitary countries. The interaction term is not significant in this case (cf. Table 8 in the Appendix). The negative impact on deficits remains similar in terms of magnitude when tax autonomy varies.

Tax autonomy itself was identified as the proper tool for federal countries. The marginal effect in this case is depicted in the bottom panel of Figure 6. Here the interaction term is significant ( $\mathrm{p}$-value $=0.03$, cf. Table 8 in the Appendix) and the figure shows that this tool becomes more effective when fiscal rules are tighter. That is, even though rules themselves do not help, an increase in tax autonomy should be considered together with the rules framework. In the policy arena, these results and in particular the fact that the effectiveness of tools to

\footnotetext{
${ }^{27}$ Estimates are shown in Table 8 of Appendix B.
} 
restrict deficits depends on the countries' constitutional structure should be carefully taken into consideration when reforms of institutions are designed and implemented.

\section{Conclusion}

The main goal of this paper is to explore which institutional arrangements help to keep the books of sub-national governments in balance. I focused on two different mechanisms which restrain sub-national jurisdictions from fiscal profligacy. On the one hand, I investigate the role of own sub-national tax resources, as higher bailout expectations due to less autonomy creates incentives to run deficits. On the other hand, I study the impact of fiscal rules, which central governments might impose to restrict the discretionary power of sub-national governments.

I conclude that a properly designed framework of fiscal rules is effective in unitary countries, but not necessarily in federations, where the larger legal autonomy of sub-national jurisdictions limits the effectiveness of the rules. For federal countries, I show that higher autonomy over tax instruments is key to prevent large deficits at the sub-national level as a form of marketpreserving federalism (Weingast, 1995). My findings show that the proper choice of fiscal arrangements depends critically on the type of government and the constitutional structure. This complements the literature of fiscal rules on the general government level, where the political environment and the electoral system, for instance, are important determinants for the effectiveness of fiscal rules (Hallerberg, Strauch, and von Hagen, 2007). As a result, a suitable framework needs to be tailored to the characteristics of a specific country. More stringent rules do not always result in more desirable outcomes and neither does a general restriction of tax autonomy.

This paper is a further step in sub-national public finance in order to explore how deficits could be avoided and large debts prevented. Several issues are left for future research. The next step should be to make use of disaggregated data for several European countries. This allows investigating additional effects which occur horizontally within the sub-national governments in combination with the vertical dimension between governmental levels, as explored in this paper. Another interesting point is the recent introduction of self-imposed fiscal rules in some regions of federal countries. Federations often grant autonomy to sub-national governments which allows them to adopt rules by themselves. Since self-imposed rules might be an important signal to the markets and reflect the preferences of voters, effects might differ from those of centrally imposed rules in federations. The evaluation of the effectiveness is an interesting task for future research. 


\section{References}

Alesina, Alberto, Ricardo Hausmann, Rudolf Hommes, and Ernesto Stein. 1999. "Budget institutions and fiscal performance in Latin America." Journal of Development Economics $59(2): 253-273$.

Alesina, Alberto and Roberto Perotti. 1996. "Fiscal Discipline and the Budget Process." American Economic Review 86 (2):401-407.

Arellano, Manuel and Stephen Bond. 1991. "Some Tests of Specification for Panel Data: Monte Carlo Evidence and an Application to Employment Equations." Review of Economic Studies $58(2): 277-297$.

Baltagi, Badi H. 2005. Econometric analysis of panel data. J. Wiley \& Sons.

Baskaran, Thushyanthan. 2011. "Fiscal decentralization, ideology, and the size of the public sector." European Journal of Political Economy 27 (3):485-506.

2012. "Soft budget constraints and strategic interactions in subnational borrowing: Evidence from the German States." Journal of Urban Economics 71 (1):114-127.

Bayoumi, Tamim and Barry Eichengreen. 1995. "Restraining Yourself: The Implications of Fiscal Rules for Economic Stabilization." Staff Papers - International Monetary Fund $42(1): 32-48$.

Beck, Thorsten, George Clarke, Alberto Groff, Philip Keefer, and Patrick Walsh. 2001. "New Tools in Comparative Political Economy: The Database of Political Institutions." The World Bank Economic Review 15 (1):165-176.

Bevilaqua, Afonso S. 2002. "State Government Bailouts in Brazil." Res working papers, InterAmerican Development Bank.

Bohn, Henning and Robert P. Inman. 1996. "Balanced Budget Rules and Public Deficits: Evidence from the U.S. States." NBER Working Papers 5533, National Bureau of Economic Research.

Bordignon, Massimo. 2006. "Fiscal Decentralization: How to Harden the Budget Constraint." In Fiscal Policy Surveillance in Europe, edited by Elena Flores Peter Wierts, Servaas Deroose and Alessandro Turrini, chap. 6. New York: Palgrave Macmillan, 109-136.

Breuillé, Marie-Laure, Thierry Madiès, and Emmanuelle Taugourdeau. 2006. "Does tax competition soften regional budget constraint?" Economics Letters 90 (2):230 - 236.

Breuillé, Marie-Laure and Marianne Vigneault. 2010. "Overlapping soft budget constraints." Journal of Urban Economics 67 (3):259-269. 
Brooks, Lea, Yosh Halberstam, and Justin Phillips. 2013. "Spending Within Limits: Evidence from Municipal Fiscal Restraints." Lincoln institute for land policy working paper.

Dahlberg, Matz and Jürgen von Hagen. 2004. "Swedish Local Government: is there a Bailout Problem." In Fiscal Federalism in Unitary States, edited by Per Molander, ZEI studies in European Economics and Law, chap. 3. Kluwer, 47-76.

Debrun, Xavier, Laurent Moulin, Alessandro Turrini, Joaquim Ayuso-i Casals, and Manmohan S. Kumar. 2008. "Tied to the Mast? National Fiscal Rules in the European Union." Economic Policy 23 (54):297-362.

Duverger, Maurice. 1954. Political Parties: Their Organization and Activity in the Modern State. Routledge.

Echavarria, Juan J., Carolina Renteria, and Roberto Steiner. 2002. "Decentralization and Bailouts in Colombia." Res working papers, Inter-American Development Bank.

Eichler, Stefan and Michael Hofmann. 2013. "Sovereign default risk and decentralization: Evidence for emerging markets." European Journal of Political Economy 32 (0):113 - 134.

European Commission. 2006. "National numerical fiscal rules and institutions for sound public finances." In Public Finances in EMU - 2006, no. 3 in European Economy.

. 2008. "Fiscal rules in the EU at national level: experiences and lessons." Presupuesto y Gasto Público 51 (2):60-82.

_. 2009. "Fiscal rules, independent institutions and medium-term budgetray frameworks." In Public Finances in EMU - 2009, no. 5 in European Economy.

Fatás, Antonio and Ilian Mihov. 2006. "The macroeconomic effects of fiscal rules in the US states." Journal of Public Economics 90 (1-2):101-117.

Feld, Lars P. and Gebhard Kirchgassner. 2006. "On the Effectiveness of Debt Brakes: The Swiss Experience." Working Paper Series 2006-21, Center for Research in Economics, Management and the Arts (CREMA).

Fink, Alexander and Thomas Stratmann. 2011. "Institutionalized Bailouts and Fiscal Policy: Consequences of Soft Budget Constraints." Kyklos 64 (3):366-395.

Foremny, Dirk. 2011. "Vertical aspects of sub-national deficits: the impact of fiscal rules and tax autonomy in European countries." MPRA Paper 32998, University Library of Munich, Germany. 
Foremny, Dirk and Juergen von Hagen. 2013a. "Fiscal Federalism in Times of Crisis: Sharing the Cost of Adjustmen." In IEB World Report on Fiscal Federalism 12. Institut d'Economia de Barcelona.

. 2013b. "Sub-national budgetary discipline during times of crisis: The impact of fiscal rules and tax autonomy." In European Economy, Economic Papers 501, Fiscal relations across government levels in times of crisis - making compatible fiscal decentralization and budgetary discipline. European Comission.

Goodspeed, Timothy J. 2002. "Bailouts in a Federation." International Tax and Public Finance $9(4): 409-421$.

Hallerberg, Mark, Rolf Strauch, and Jürgen von Hagen. 2007. "The design of fiscal rules and forms of governance in European Union countries." European Journal of Political Economy $23(2): 338-359$.

- 2009. Fiscal governance in Europe. New York: Cambridge University Press.

Hallerberg, Mark and Jürgen von Hagen. 1999. "Electoral Institutions, Cabinet Negotiations, and Budget Deficits in the European Union." In Fiscal Institutions and Fiscal Performance, NBER Chapters. National Bureau of Economic Research, 209-232.

Iara, Anna and Guntram Wolff. 2011. "Rules and Risk in the euro area." Bruegel Working Paper 10.

Inman, Robert P. 2001. "Transfers and Bailouts: Institutions for Enforcing Local Fiscal Discipline." Constitutional Political Economy 12 (2):141-160.

Kornai, János, Eric Maskin, and Gérard Roland. 2003. "Understanding the Soft Budget Constraint." Journal of Economic Literature 41 (4):1095-1136.

Krogstrup, Signe and Charles Wyplosz. 2010. "A common pool theory of supranational deficit ceilings." European Economic Review 54 (2):273 - 282.

Köthenbürger, Marko. 2007. "Ex-post redistribution in a federation: Implications for corrective policy." Journal of Public Economics 91 (3-4):481 - 496.

Neyapti, Bilin. 2010. "Fiscal decentralization and deficits: International evidence." European Journal of Political Economy 26 (2):155-166.

Nicolini, Juan Pablo, Josefina Posadas, Juan Sanguinetti, Pablo Sanguinetti, and Mariano Tommasi. 2002. "Decentralization, Fiscal Discipline in Sub-National Governments and the Bailout Problem: The Case of Argentina." Res working papers, Inter-American Development Bank. 
OECD. 1999. Taxing powers of state and local government. Organisation for Economic Cooperation and Development.

Pettersson-Lidbom, Per. 2010. "Dynamic Commitment and the Soft Budget Constraint: An Empirical Test." American Economic Journal: Economic Policy 2 (3):154-79.

Plekhanov, Alexander and Raju Singh. 2007. "How Should Subnational Government Borrowing Be Regulated? Some Cross-Country Empirical Evidence." IMF Staff Papers 53 (3).

Poterba, James M. 1994. "State Responses to Fiscal Crises: The Effects of Budgetary Institutions and Politics." Journal of Political Economy 102 (4):799-821.

. 1996. "Budget Institutions and Fiscal Policy in the U.S. States." The American Economic Review 86 (2):395-400.

Rodden, Jonathan A. 2002. "The Dilemma of Fiscal Federalism: Grants and Fiscal Performance around the World." American Journal of Political Science 46 (3):670-687.

2006. Hamilton's Paradox: The Promise and Peril of Fiscal Federalism. Cambridge Studies in Comparative Politics. Cambridge University Press.

Rodden, Jonathan A., Gunnar S. Eskeland, and Jannie Litvack. 2003. Fiscal Decentralization and the Challenge of Hard Budget Constraints. The MIT Press.

Seitz, Helmut. 2000. "Subnational Bailouts in Germany." Res working papers, Inter-American Development Bank.

Sorribas-Navarro, Pilar. 2011. "Bailouts in a fiscal federal system: Evidence from Spain." European Journal of Political Economy 27 (1):154-170.

Stegarescu, Dan. 2005. "Public Sector Decentralization: Measurement Concepts and Recent International Trends." Fiscal Studies 26 (3):301-333.

Sutherland, Douglas, Robert Price, and Isabelle Joumard. 2005. "Fiscal Rules for Sub-central Governments: Design and Impact." OECD Economics Department Working Papers 465, OECD.

Taagepera, Rein and Matthew Soberg Shugart. 1993. "Predicting the Number of Parties: A Quantitative Model of Duverger's Mechanical Effect." The American Political Science Review 87 (2):455-464.

Velasco, Andrés. 2000. "Debts and deficits with fragmented fiscal policymaking." Journal of Public Economics 76 (1):105 - 125. 
Vigneault, Marianne. 2006. "Grants and Soft Budget Constraints." In Intergovernmental Fiscal Transfers: Principles and Practice, edited by Robin Boadway and Anwar Shah, chap. 5. World Bank Publications, 133-171.

von Hagen, Jürgen. 1991. "A note on the empirical effectiveness of formal fiscal restraints." Journal of Public Economics 44 (2):199 - 210.

- 2002. "Fiscal Rules, Fiscal Institutions, and Fiscal Performance." The Economic and Social Review 33 (3):263-284.

- 2005. "Political Economy of Fiscal Institutions." In Oxford Handbook on Political Economy, edited by Barry Weingast and Donald Wittman. Oxford University Press, 464478.

2006. "Fiscal Rules and Fiscal Performance in the European Union and Japan." Monetary and Economic Studies 24 (1):25-60.

von Hagen, Jürgen, Massimo Bordignon, Bhajan S. Grewal, Per Petterson, Helmut Seitz, and Matz Dahlberg. 2000. "Subnational Government Bailouts in OECD Countries: Four Case Studies." Res working papers, Inter-American Development Bank.

von Hagen, Jürgen and Barry Eichengreen. 1996. "Federalism, Fiscal Restraints, and European Monetary Union." American Economic Review 86 (2):134-138.

von Hagen, Jürgen and Ian J. Harden. 1994. "National budget processes and fiscal performance." European Economy (Reports and Studies) 3:311-418.

1995. "Budget processes and commitment to fiscal discipline." European Economic Review 39 (3-4):771 - 779.

von Hagen, Jürgen and Guntram B. Wolff. 2006. "What do deficits tell us about debt? Empirical evidence on creative accounting with fiscal rules in the EU." Journal of Banking and Finance 30 (12):3259-3279.

Weingast, Barry R. 1995. "The Economic Role of Political Institutions: Market-Preserving Federalism and Economic Development." Journal of Law, Economics, E Organization 11 (1):131.

Wildasin, David E. 1997. "Externalities and bailouts: Hard and soft budget constraints in intergovernmental fiscal relations." Policy Research Working Paper Series 1843, The World Bank. 


\section{Graphs and tables}
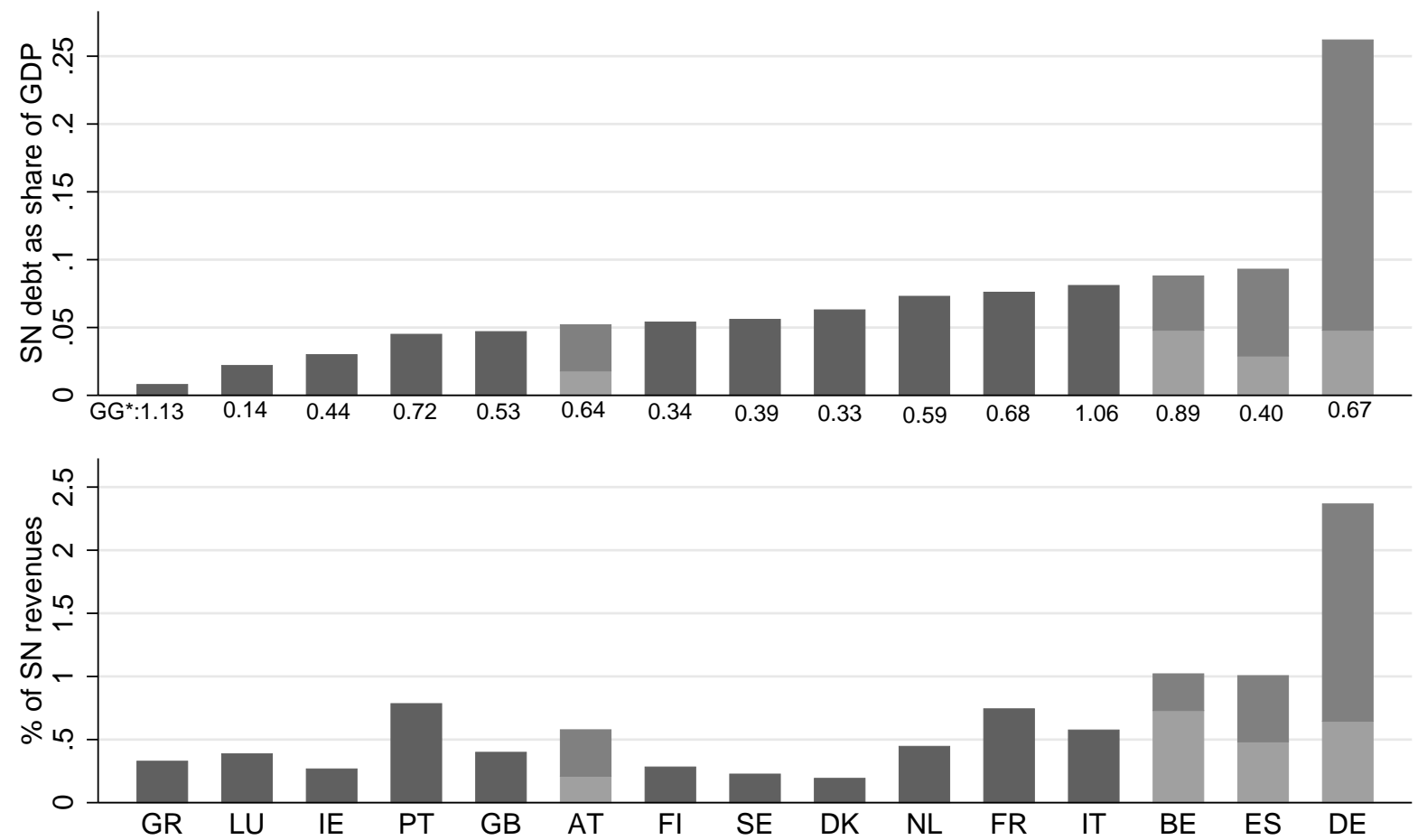

sub-national sector (unitary)
regional sector (federal) * general government (GG) value

Notes: Consolidated outstanding debt in 2008. Top panel: as a share of GDP. Values below the graphs represent the values at the general government level. Bottom panel: as share of revenues collected at the respective level of government.

Figure 1: Sub-national outstanding debt 


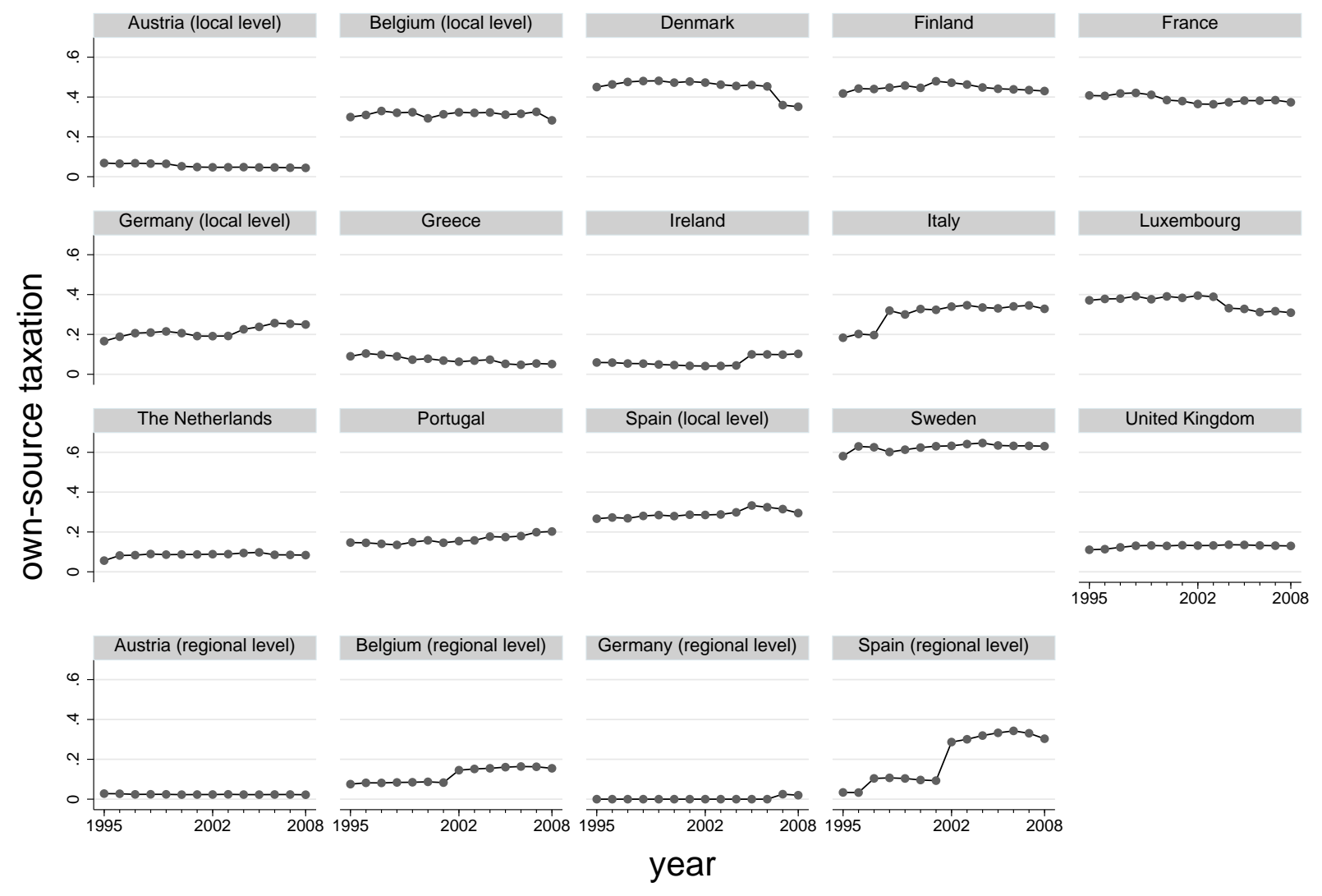

Notes: Share of tax revenues under discretion of the respective governmental level. Classification of autonomy according to the OECD fiscal decentralization database and national tax legislation.

Figure 2: Revenues from own-source taxation 


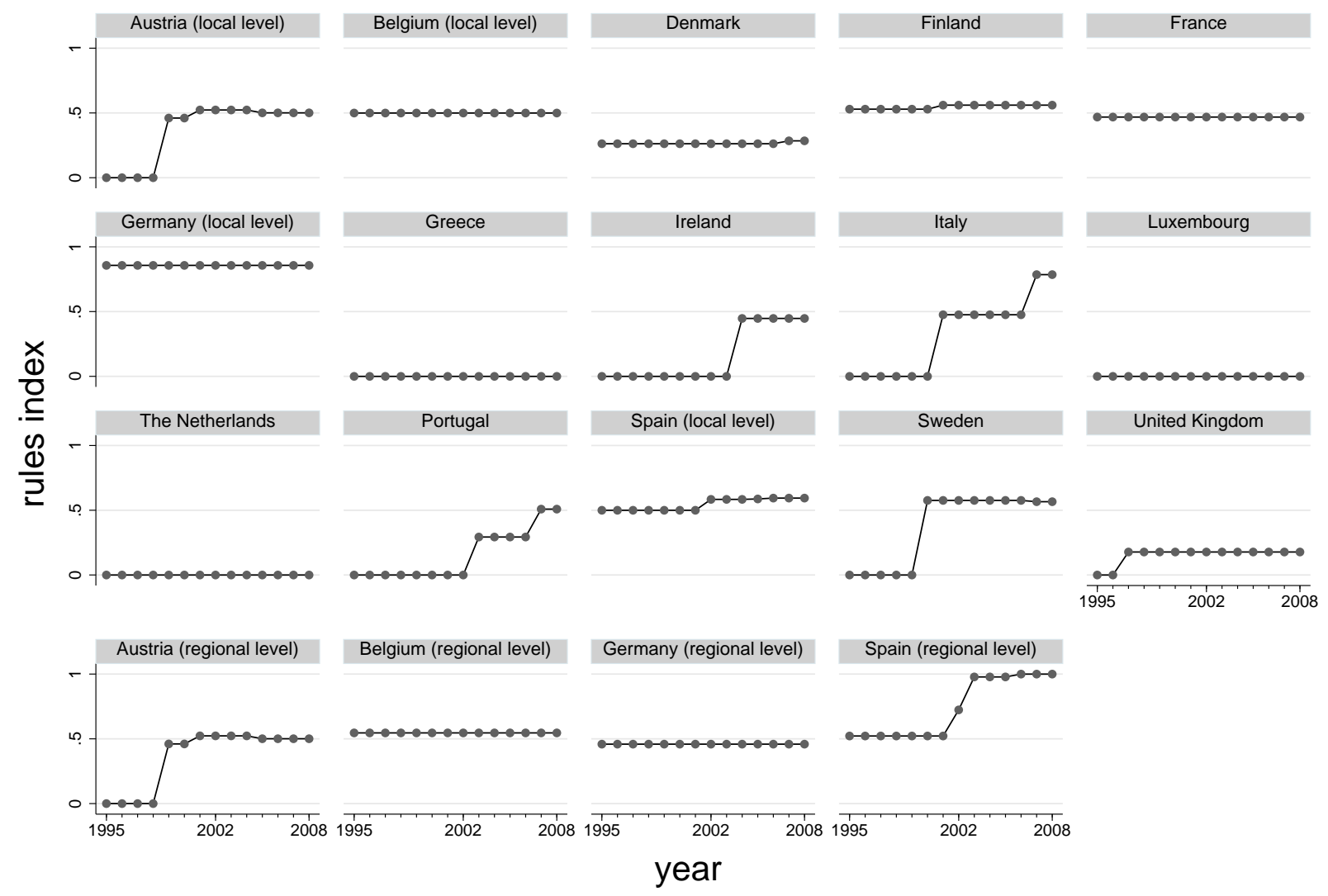

Notes: Fiscal rules index. Survey information is taken from European Commission (2009). Own calculations according to appendix C.

Figure 3: Fiscal rules index 


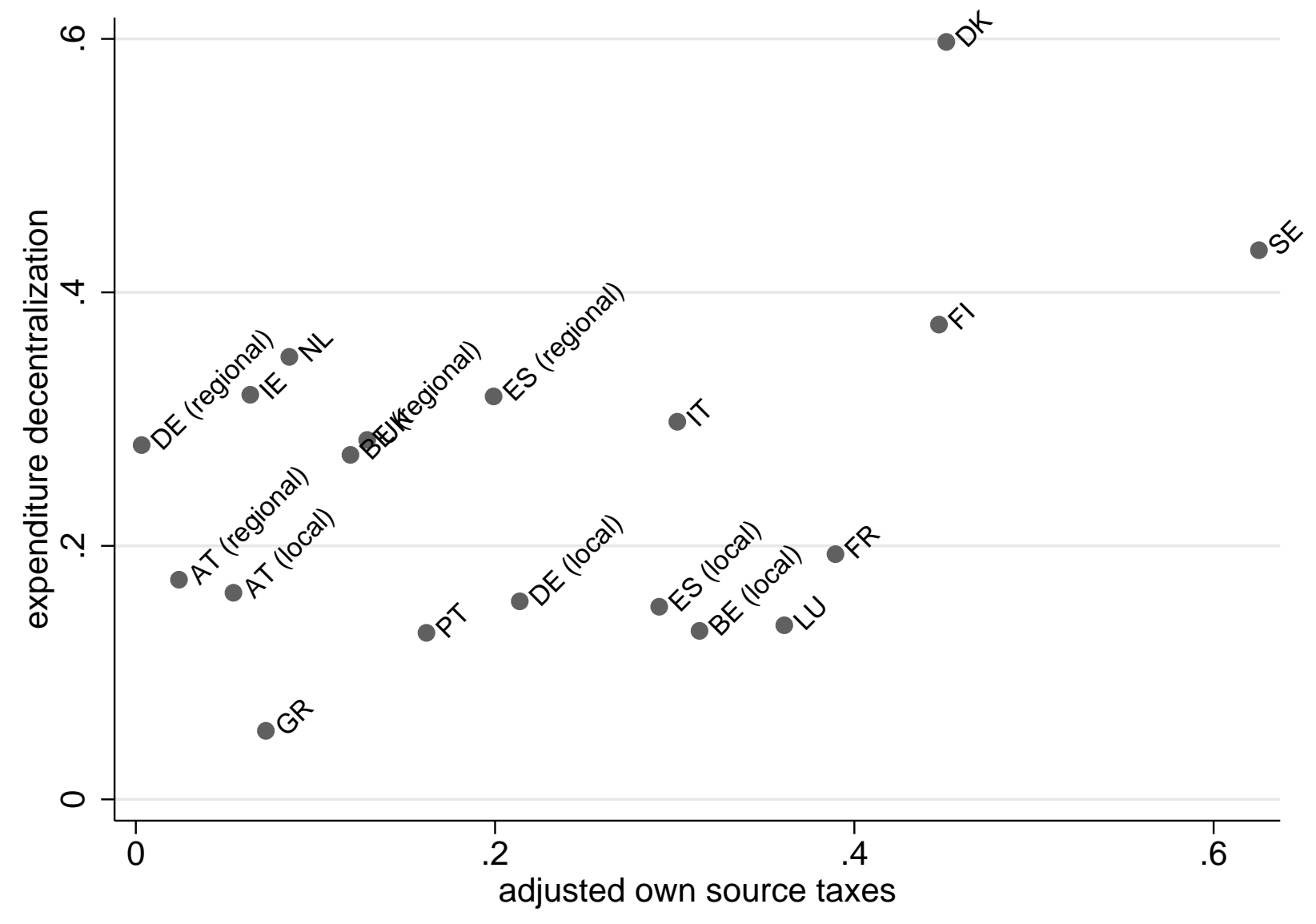

Notes: Mean by country over 1995-2008. Vertical axis: share of expenditures in general government expenditures, horizontal axis: revenues from own-source taxation as share of total sub-national revenues.

Figure 4: Decentralization over 1995-2008 


\begin{tabular}{|c|c|c|c|c|c|c|}
\hline Variable & Source & & Mean & Std. Dev. & Min & Max \\
\hline \multicolumn{7}{|c|}{ Dependent variables } \\
\hline \multirow[t]{3}{*}{ deficit/revenues } & Eurostat & overall & 0.006 & 0.034 & -0.100 & 0.112 \\
\hline & & between & & 0.022 & -0.042 & 0.062 \\
\hline & & within & & 0.026 & -0.087 & 0.101 \\
\hline \multirow[t]{3}{*}{ deficit/gdp } & Eurostat & overall & 0.001 & 0.004 & -0.013 & 0.016 \\
\hline & & between & & 0.003 & -0.002 & 0.008 \\
\hline & & within & & 0.003 & -0.014 & 0.012 \\
\hline \multirow{4}{*}{$\begin{array}{l}\text { Tax autonomy } \\
\operatorname{tax}^{1}\end{array}$} & & & & & & \\
\hline & OECD, & overall & 0.227 & 0.172 & 0.000 & 0.646 \\
\hline & own calculations & between & & 0.173 & 0.003 & 0.625 \\
\hline & & within & & 0.037 & 0.061 & 0.370 \\
\hline \multirow{2}{*}{$\begin{array}{l}\operatorname{tax} * \text { federal } \\
\operatorname{tax} * \text { unitary }\end{array}$} & & overall & 0.152 & 0.122 & 0.000 & 0.343 \\
\hline & & overall & 0.281 & 0.184 & 0.041 & 0.646 \\
\hline \multicolumn{7}{|l|}{ Fiscal rules } \\
\hline \multirow[t]{3}{*}{ rules $^{2}$} & $\mathrm{EC}$ & overall & 0.358 & 0.228 & 0.000 & 1.000 \\
\hline & own calculations & between & & 0.242 & 0.000 & 0.857 \\
\hline & & within & & 0.146 & -0.011 & 0.826 \\
\hline \multirow{2}{*}{\multicolumn{2}{|c|}{$\begin{array}{l}\text { rules } * \text { federal } \\
\text { rules } * \text { unitary }\end{array}$}} & overall & 0.229 & 0.304 & 0.000 & 1.000 \\
\hline & & overall & 0.128 & 0.210 & 0.000 & 0.785 \\
\hline \multicolumn{7}{|l|}{ Controls } \\
\hline \multirow[t]{3}{*}{$d e f \_c g \_r e v^{3}$} & Eurostat & overall & 0.081 & 0.113 & -0.189 & 0.621 \\
\hline & & between & & 0.074 & -0.031 & 0.276 \\
\hline & & within & & 0.087 & -0.169 & 0.556 \\
\hline \multirow[t]{3}{*}{$e d e c^{4}$} & Eurostat & overall & 0.254 & 0.131 & 0.043 & 0.659 \\
\hline & & between & & 0.131 & 0.054 & 0.598 \\
\hline & & within & & 0.029 & 0.116 & 0.360 \\
\hline \multirow[t]{3}{*}{ intexp_rev $v^{5}$} & Eurostat & overall & 0.942 & 1.307 & 0.004 & 5.875 \\
\hline & & between & & 1.303 & 0.007 & 5.382 \\
\hline & & within & & 0.306 & 0.042 & 2.256 \\
\hline \multirow[t]{3}{*}{ outgap } & Eurostat & overall & 0.374 & 1.648 & -4.707 & 5.209 \\
\hline & & between & & 0.372 & -0.111 & 1.429 \\
\hline & & within & & 1.608 & -4.540 & 5.376 \\
\hline \multirow[t]{3}{*}{$I_{\text {population }}$} & Eurostat & overall & 0.905 & 0.071 & 0.708 & 1.000 \\
\hline & & between & & 0.073 & 0.713 & 1.000 \\
\hline & & within & & 0.002 & 0.900 & 0.911 \\
\hline \multirow[t]{3}{*}{ depratio ${ }^{6}$} & Eurostat & overall & 0.670 & 0.012 & 0.636 & 0.690 \\
\hline & & between & & 0.011 & 0.646 & 0.685 \\
\hline & & within & & 0.006 & 0.640 & 0.687 \\
\hline \multirow[t]{3}{*}{ unempl ${ }^{7}$} & Eurostat & overall & 0.075 & 0.031 & 0.019 & 0.184 \\
\hline & & between & & 0.027 & 0.034 & 0.123 \\
\hline & & within & & 0.017 & 0.036 & 0.137 \\
\hline
\end{tabular}

Definitions: ${ }^{1}$ revenues from own-source taxes as share of total revenues; ${ }^{2}$ fiscal rules index; ${ }^{3}$ central government deficit as share of revenues; ${ }^{4}$ share of sub-national expenditures in general government expenditures; ${ }^{5}$ interest expenditures as share of revenues; ${ }^{6}$ share of working $\$ 2$ pulation in total population; ${ }^{7}$ unemployment rate 


\begin{tabular}{llllrrr}
\hline Variable & Source & & Mean & Std. Dev. & Min & Max \\
\hline ideology $^{1}$ & World Bank, & overall & 0.376 & 0.327 & 0.000 & 1.000 \\
& own calculations & between & & 0.131 & 0.089 & 0.589 \\
& Beck et al. (2001) & within & & 0.301 & -0.213 & 1.171 \\
herfgov $^{2}$ & World Bank & overall & 0.666 & 0.270 & 0.181 & 1.000 \\
& Beck et al. (2001) & between & & 0.257 & 0.221 & 1.000 \\
& & within & & 0.101 & 0.350 & 1.004 \\
disctrict $^{3}$ & World Bank & overall & 9.402 & 6.050 & 1.000 & 22.500 \\
& Beck et al. (2001) & between & & 5.712 & 1.000 & 20.300 \\
& & within & & 2.364 & 5.052 & 25.352 \\
contract $^{4}$ & Hallerberg et al. (2009) & overall & 0.425 & 0.495 & 0.000 & 1.000 \\
& & between & & 0.465 & 0.000 & 1.000 \\
& & within & & 0.199 & 0.068 & 1.282 \\
debt_gg_gdp $^{5}$ & Eurostat & overall & 0.634 & 0.265 & 0.061 & 1.304 \\
& & between & & 0.255 & 0.071 & 1.102 \\
& & within & & 0.091 & 0.406 & 1.019 \\
\hline
\end{tabular}

Definitions: ${ }^{1}$ index from zero (single party left-wing) to one (single party right-wing); ${ }^{2}$ Herfindahl measure of fractionalization (probability that two randomly chosen individuals belong to the same political group); ${ }^{3}$ district magnitude; ${ }^{4}$ form of fiscal governance; ${ }^{5}$ debt at the general government level as share of gdp

Table 2: Summary statistics: Central government characteristics 


\begin{tabular}{|c|c|c|c|c|}
\hline \multirow{2}{*}{$\begin{array}{l}\text { Dependent Variable } \\
\text { Rules Index }\end{array}$} & \multirow{2}{*}{$\frac{\text { Collapsed Model }}{\text { (a) }}$} & \multicolumn{2}{|c|}{ Pooled Model } & \multirow{2}{*}{$\frac{\text { Fixed Effects }}{(\mathrm{d})}$} \\
\hline & & (b) & (c) & \\
\hline \multicolumn{5}{|l|}{ Political variables } \\
\hline herfgov & $\begin{array}{c}-0.499^{* *} \\
(0.180)\end{array}$ & $\begin{array}{c}-0.157^{* *} \\
(0.072)\end{array}$ & $\begin{array}{l}-0.063 \\
(0.060)\end{array}$ & $\begin{array}{c}-0.323^{* * *} \\
(0.101)\end{array}$ \\
\hline \multirow[t]{2}{*}{ election } & -0.108 & 0.011 & 0.012 & 0.019 \\
\hline & $(0.181)$ & $(0.008)$ & $(0.009)$ & $(0.012)$ \\
\hline ideology & $\begin{array}{l}-0.087 \\
(0.080)\end{array}$ & $\begin{array}{l}-0.011 \\
(0.027)\end{array}$ & $\begin{array}{l}-0.013 \\
(0.022)\end{array}$ & $\begin{array}{c}0.017 \\
(0.022)\end{array}$ \\
\hline district & $\begin{array}{c}0.011 \\
(0.006)\end{array}$ & $\begin{array}{c}0.003 \\
(0.005)\end{array}$ & $\begin{array}{c}0.003 \\
(0.003)\end{array}$ & $\begin{array}{c}0.014^{* * * *} \\
(0.005)\end{array}$ \\
\hline contract & $\begin{array}{c}-0.391^{* *} \\
(0.142)\end{array}$ & $\begin{array}{l}-0.105^{*} \\
(0.056)\end{array}$ & $\begin{array}{l}-0.053 \\
(0.047)\end{array}$ & $\begin{array}{c}-0.218^{* * *} \\
(0.052)\end{array}$ \\
\hline \multicolumn{5}{|c|}{ Budgetary variables } \\
\hline def_rev & $\begin{array}{l}-0.553 \\
(1.366)\end{array}$ & $\begin{array}{l}-0.131 \\
(0.199)\end{array}$ & $\begin{array}{l}-0.143 \\
(0.191)\end{array}$ & $\begin{array}{l}0.010 \\
(0.207)\end{array}$ \\
\hline$d e f \_r e v_{(t-1)}$ & & $\begin{array}{l}-0.151 \\
(0.202)\end{array}$ & $\begin{array}{l}-0.104 \\
(0.193)\end{array}$ & $\begin{array}{l}-0.320 \\
(0.252)\end{array}$ \\
\hline$d e b t_{-} g g_{-} g d p_{(t-1)}$ & $\begin{array}{l}-0.028 \\
(0.132)\end{array}$ & $\begin{array}{l}-0.004 \\
(0.075)\end{array}$ & $\begin{array}{l}-0.008 \\
(0.040)\end{array}$ & $\begin{array}{c}0.255^{* *} \\
(0.124)\end{array}$ \\
\hline \multicolumn{5}{|l|}{ Timing } \\
\hline & $\begin{array}{c}0.291^{* *} \\
(0.122)\end{array}$ & $\begin{array}{l}0.042^{*} \\
(0.022)\end{array}$ & $\begin{array}{c}0.048^{* *} \\
(0.020)\end{array}$ & $\begin{array}{l}0.053^{*} \\
(0.020)\end{array}$ \\
\hline trend & & $\begin{array}{c}0.014^{* * *} \\
(0.004)\end{array}$ & $\begin{array}{c}0.002 \\
(0.003)\end{array}$ & $\begin{array}{c}0.014^{* * *} \\
(0.005)\end{array}$ \\
\hline
\end{tabular}




\begin{tabular}{|c|c|c|c|c|}
\hline \multicolumn{5}{|c|}{...continued from previous page } \\
\hline Rules Index & (a) & (b) & (c) & (d) \\
\hline \multicolumn{5}{|l|}{ Controls } \\
\hline depratio & $\begin{array}{c}1.721 \\
(2.582)\end{array}$ & $\begin{array}{c}2.410 \\
(1.676)\end{array}$ & $\begin{array}{c}0.599 \\
(0.984)\end{array}$ & $\begin{array}{c}4.941^{* *} \\
(2.294)\end{array}$ \\
\hline \multirow[t]{2}{*}{ outgap } & 0.039 & -0.003 & 0.001 & $-0.012^{* *}$ \\
\hline & $(0.028)$ & $(0.005)$ & $(0.005)$ & $(0.005)$ \\
\hline \multirow[t]{2}{*}{ unempl } & $2.599^{*}$ & 0.915 & 0.494 & -0.506 \\
\hline & $(1.428)$ & $(0.564)$ & $(0.367)$ & $(0.785)$ \\
\hline \multirow[t]{2}{*}{$I_{\text {population }}$} & 0.941 & $1.162^{* * *}$ & $0.483^{*}$ & 6.598 \\
\hline & $(0.727)$ & $(0.425)$ & $(0.253)$ & $(10.436)$ \\
\hline \multirow[t]{2}{*}{ edec } & 0.465 & 0.188 & 0.127 & -0.279 \\
\hline & $(0.279)$ & $(0.160)$ & $(0.092)$ & $(0.270)$ \\
\hline \multirow[t]{2}{*}{$\operatorname{tax}$} & $0.684^{* *}$ & $0.781^{* * *}$ & $0.263^{* *}$ & $1.396^{* * *}$ \\
\hline & $(0.283)$ & $(0.150)$ & $(0.112)$ & $(0.239)$ \\
\hline \multirow[t]{2}{*}{ local dummy } & $0.158^{*}$ & $0.282^{* * *}$ & $0.093^{* * *}$ & \\
\hline & $(0.078)$ & $(0.056)$ & $(0.034)$ & \\
\hline \multirow[t]{2}{*}{ regional dummy } & $0.227 * * *$ & $0.332^{* * *}$ & $0.109^{* * *}$ & \\
\hline & $(0.079)$ & $(0.055)$ & $(0.037)$ & \\
\hline \multirow[t]{2}{*}{$L D V$} & & & $0.648^{* * *}$ & \\
\hline & & & $(0.071)$ & \\
\hline \multirow[t]{2}{*}{ Constant } & -1.935 & $-2.735^{* *}$ & -0.881 & \\
\hline & $(1.831)$ & $(1.281)$ & $(0.739)$ & \\
\hline Fixed Effects & No & No & No & Yes \\
\hline$R^{2}$ & 0.888 & 0.467 & 0.822 & 0.620 \\
\hline \multicolumn{5}{|c|}{$\begin{array}{l}\text { Robust standard errors in parentheses } \\
\text { *** } \mathrm{p}<0.01 \text {, ** } \mathrm{p}<0.05,{ }^{*} \mathrm{p}<0.1 \\
\text { (1) } \mathrm{n}=41,(2)-(4) \mathrm{n}=247 \mathrm{~N}=19 \mathrm{~T}=14\end{array}$} \\
\hline
\end{tabular}

Notes: Model (a): aggregated estimation according to Equation 2; Models (b) and (c): pooled regression with panel corrected standard errors; Model (d): fixed effect estimation with standard errors robust to heteroskedasticity and autocorrelation (Newey-West)

Table 3: Determinants of fiscal rules 


\begin{tabular}{|c|c|c|c|c|c|c|}
\hline \multirow{2}{*}{$\begin{array}{l}\text { Dependent Variable } \\
\text { Rules Index }\end{array}$} & \multicolumn{6}{|c|}{ Fixed Effect Panel Model } \\
\hline & (a) & (b) & (c) & $(d)$ & (e) & (f) \\
\hline \multicolumn{7}{|c|}{ Herfindahl index (fractionalization) } \\
\hline herfgov & & $\begin{array}{c}-0.297^{* * *} \\
(0.100)\end{array}$ & $\begin{array}{c}-0.301 * * * \\
(0.097)\end{array}$ & $\begin{array}{c}-0.345^{* * *} \\
(0.103)\end{array}$ & $\begin{array}{c}-0.279^{* * *} \\
(0.103)\end{array}$ & \\
\hline herfgov $*$ federal & $\begin{array}{l}-0.005 \\
(0.089)\end{array}$ & & & & & $\begin{array}{l}-0.061 \\
(0.090)\end{array}$ \\
\hline $\operatorname{herfgov}_{(t-1)} *$ federal & $\begin{array}{c}0.244^{* * *} \\
(0.082)\end{array}$ & & & & & $\begin{array}{c}0.280^{* * *} \\
(0.080)\end{array}$ \\
\hline herfgov * unitary & $\begin{array}{l}-0.261 \\
(0.179)\end{array}$ & & & & & $\begin{array}{l}-0.182 \\
(0.147)\end{array}$ \\
\hline $\operatorname{herfgov}_{(t-1)} *$ unitary & $\begin{array}{c}-0.376^{*} \\
(0.213) \\
\end{array}$ & & & & & $\begin{array}{c}-0.499^{* * * *} \\
(0.190)\end{array}$ \\
\hline $\begin{array}{l}\text { Election year } \\
\text { election }\end{array}$ & $\begin{array}{c}0.012 \\
(0.011)\end{array}$ & & $\begin{array}{c}0.013 \\
(0.012)\end{array}$ & $\begin{array}{c}0.017 \\
(0.012)\end{array}$ & $\begin{array}{c}0.011 \\
(0.013)\end{array}$ & \\
\hline election $*$ federal & & $\begin{array}{c}0.030 \\
(0.022)\end{array}$ & & & & $\begin{array}{c}0.029 \\
(0.019)\end{array}$ \\
\hline election $_{(t-1)} *$ federal & & $\begin{array}{c}0.009 \\
(0.016)\end{array}$ & & & & $\begin{array}{l}-0.006 \\
(0.012)\end{array}$ \\
\hline election $*$ unitary & & $\begin{array}{c}0.002 \\
(0.019)\end{array}$ & & & & $\begin{array}{l}-0.003 \\
(0.017)\end{array}$ \\
\hline election $_{(t-1)} *$ unitary & & $\begin{array}{l}-0.008 \\
(0.021)\end{array}$ & & & & $\begin{array}{l}-0.009 \\
(0.018)\end{array}$ \\
\hline \multicolumn{7}{|c|}{ Ideology (1=right-wing single party) } \\
\hline ideology & $\begin{array}{c}0.044^{* *} \\
(0.021)\end{array}$ & $\begin{array}{c}0.032 \\
(0.022)\end{array}$ & & $\begin{array}{c}0.064^{* * *} \\
(0.021)\end{array}$ & $\begin{array}{c}0.022 \\
(0.022)\end{array}$ & \\
\hline$i d e o l o g y *$ federal & & & $\begin{array}{l}-0.049 \\
(0.031)\end{array}$ & & & $\begin{array}{c}0.021 \\
(0.023)\end{array}$ \\
\hline$i_{\text {deology }}(t-1) *$ federal & & & $\begin{array}{c}0.016 \\
(0.025)\end{array}$ & & & $\begin{array}{l}-0.009 \\
(0.023)\end{array}$ \\
\hline ideology $*$ unitary & & & $\begin{array}{c}0.043 \\
(0.041)\end{array}$ & & & $\begin{array}{l}0.058^{*} \\
(0.032)\end{array}$ \\
\hline ideology $_{(t-1)} *$ unitary & & & $\begin{array}{c}0.054 \\
(0.037) \\
\end{array}$ & & & $\begin{array}{c}0.044 \\
(0.033)\end{array}$ \\
\hline $\begin{array}{l}\text { District magnitude } \\
\text { district }\end{array}$ & $\begin{array}{c}0.015^{* * *} \\
(0.004)\end{array}$ & $\begin{array}{c}0.014^{* * *} \\
(0.005)\end{array}$ & $\begin{array}{c}0.016^{* * *} \\
(0.005)\end{array}$ & & $\begin{array}{c}0.013^{* * *} \\
(0.005)\end{array}$ & \\
\hline district $*$ federal & & & & $\begin{array}{l}-0.004 \\
(0.005)\end{array}$ & & $\begin{array}{c}0.007 \\
(0.006)\end{array}$ \\
\hline $\operatorname{district}_{(t-1)} *$ federal & & & & $\begin{array}{c}0.005 \\
(0.004)\end{array}$ & & $\begin{array}{l}0.007 * * \\
(0.004)\end{array}$ \\
\hline district $*$ unitary & & & & $\begin{array}{l}0.008^{*} \\
(0.004)\end{array}$ & & $\begin{array}{l}0.006 \\
(0.004)\end{array}$ \\
\hline $\operatorname{district~}_{(t-1)} *$ unitary & & & & $\begin{array}{c}0.015^{* * *} \\
(0.003)\end{array}$ & & $\begin{array}{c}0.016^{* * *} \\
(0.002)\end{array}$ \\
\hline
\end{tabular}




\begin{tabular}{|c|c|c|c|c|c|c|}
\hline \multicolumn{7}{|c|}{...continued from previous page } \\
\hline Rules Index & (a) & (b) & (c) & (d) & (e) & (f) \\
\hline $\begin{array}{l}\text { Contract } \\
\text { contract }\end{array}$ & $\begin{array}{c}-0.226^{* * *} \\
(0.053)\end{array}$ & $\begin{array}{c}-0.219^{* * *} \\
(0.053)\end{array}$ & $\begin{array}{c}-0.235^{* * *} \\
(0.051)\end{array}$ & $\begin{array}{c}-0.220^{* * *} \\
(0.053)\end{array}$ & & \\
\hline contract $*$ federal & & & & & $\begin{array}{c}-0.269^{* * *} \\
(0.069)\end{array}$ & $\begin{array}{c}-0.273^{* * *} \\
(0.063)\end{array}$ \\
\hline $\operatorname{contract}_{(t-1)} *$ federal & & & & & $\begin{array}{l}-0.003 \\
(0.026)\end{array}$ & $\begin{array}{c}0.045 \\
(0.029)\end{array}$ \\
\hline contract $*$ unitary & & & & & $\begin{array}{l}-0.070 \\
(0.044)\end{array}$ & $\begin{array}{l}-0.074 \\
(0.054)\end{array}$ \\
\hline $\operatorname{contract}_{(t-1)} *$ unitary & & & & & $\begin{array}{l}-0.057 \\
(0.067)\end{array}$ & $\begin{array}{c}-0.182^{* *} \\
(0.076)\end{array}$ \\
\hline \multicolumn{7}{|l|}{ Controls } \\
\hline def_rev & $\begin{array}{l}-0.169 \\
(0.188)\end{array}$ & $\begin{array}{l}-0.119 \\
(0.216)\end{array}$ & $\begin{array}{l}-0.221 \\
(0.206)\end{array}$ & $\begin{array}{c}0.042 \\
(0.196)\end{array}$ & $\begin{array}{l}-0.133 \\
(0.213)\end{array}$ & $\begin{array}{l}-0.095 \\
(0.174)\end{array}$ \\
\hline$d e f \_r e v_{(t-1)}$ & $\begin{array}{l}-0.228 \\
(0.215)\end{array}$ & $\begin{array}{l}-0.274 \\
(0.247)\end{array}$ & $\begin{array}{l}-0.250 \\
(0.249)\end{array}$ & $\begin{array}{l}-0.206 \\
(0.239)\end{array}$ & $\begin{array}{l}-0.198 \\
(0.244)\end{array}$ & $\begin{array}{l}-0.265 \\
(0.215)\end{array}$ \\
\hline unempl & $\begin{array}{l}-0.783 \\
(1.142)\end{array}$ & $\begin{array}{c}0.437 \\
(1.388)\end{array}$ & $\begin{array}{c}1.047 \\
(1.404)\end{array}$ & $\begin{array}{c}0.422 \\
(1.424)\end{array}$ & $\begin{array}{c}0.357 \\
(1.379)\end{array}$ & $\begin{array}{l}-1.081 \\
(1.123)\end{array}$ \\
\hline $\operatorname{unempl}_{(t-1)}$ & $\begin{array}{l}-0.227 \\
(0.978)\end{array}$ & $\begin{array}{l}-0.938 \\
(1.200)\end{array}$ & $\begin{array}{l}-1.476 \\
(1.249)\end{array}$ & $\begin{array}{l}-0.667 \\
(1.191)\end{array}$ & $\begin{array}{l}-0.883 \\
(1.188)\end{array}$ & $\begin{array}{l}-0.131 \\
(0.988)\end{array}$ \\
\hline $\operatorname{tax}$ & $\begin{array}{l}0.477^{*} \\
(0.257)\end{array}$ & $\begin{array}{l}0.607^{*} \\
(0.314)\end{array}$ & $\begin{array}{c}0.683^{* *} \\
(0.303)\end{array}$ & $\begin{array}{c}0.681^{* *} \\
(0.300)\end{array}$ & $\begin{array}{l}0.619^{*} \\
(0.321)\end{array}$ & $\begin{array}{l}0.500^{*} \\
(0.283)\end{array}$ \\
\hline $\operatorname{tax}_{(t-1)}$ & $\begin{array}{c}0.927^{* * *} \\
(0.289)\end{array}$ & $\begin{array}{c}1.041^{* * *} \\
(0.317)\end{array}$ & $\begin{array}{c}1.053^{* * *} \\
(0.303)\end{array}$ & $\begin{array}{c}1.019^{* * *} \\
(0.306)\end{array}$ & $\begin{array}{c}1.030^{* * *} \\
(0.319)\end{array}$ & $\begin{array}{c}0.888^{* * *} \\
(0.298)\end{array}$ \\
\hline depratio & $\begin{array}{l}4.292^{* *} \\
(1.886)\end{array}$ & $\begin{array}{l}5.258^{* *} \\
(2.177)\end{array}$ & $\begin{array}{c}6.523^{* * *} \\
(2.210)\end{array}$ & $\begin{array}{c}6.853^{* * *} \\
(2.269)\end{array}$ & $\begin{array}{l}5.091^{* *} \\
(2.229)\end{array}$ & $\begin{array}{c}5.582^{* * *} \\
(1.929)\end{array}$ \\
\hline outgap & $\begin{array}{l}-0.005 \\
(0.005)\end{array}$ & $\begin{array}{l}-0.007 \\
(0.006)\end{array}$ & $\begin{array}{l}-0.005 \\
(0.006)\end{array}$ & $\begin{array}{l}-0.006 \\
(0.006)\end{array}$ & $\begin{array}{l}-0.006 \\
(0.006)\end{array}$ & $\begin{array}{l}-0.006 \\
(0.006)\end{array}$ \\
\hline$d e b t_{-} g g_{-} g d p$ & $\begin{array}{c}0.334^{* * *} \\
(0.099)\end{array}$ & $\begin{array}{c}0.276^{* *} \\
(0.119)\end{array}$ & $\begin{array}{c}0.320^{* * *} \\
(0.116)\end{array}$ & $\begin{array}{c}0.234^{* *} \\
(0.118)\end{array}$ & $\begin{array}{c}0.233^{*} \\
(0.121)\end{array}$ & $\begin{array}{c}0.375^{* * *} \\
(0.110)\end{array}$ \\
\hline$I_{\text {population }}$ & $\begin{array}{c}3.880 \\
(9.337)\end{array}$ & $\begin{array}{c}-1.906 \\
(11.361)\end{array}$ & $\begin{array}{l}-10.029 \\
(12.072)\end{array}$ & $\begin{array}{c}0.944 \\
(11.130)\end{array}$ & $\begin{array}{c}-0.481 \\
(11.493)\end{array}$ & $\begin{array}{c}-0.778 \\
(9.967)\end{array}$ \\
\hline edec & $\begin{array}{c}-0.491^{*} \\
(0.280)\end{array}$ & $\begin{array}{l}-0.430 \\
(0.283)\end{array}$ & $\begin{array}{c}-0.528^{*} \\
(0.299)\end{array}$ & $\begin{array}{l}-0.329 \\
(0.301)\end{array}$ & $\begin{array}{l}-0.424 \\
(0.292)\end{array}$ & $\begin{array}{c}-0.500^{*} \\
(0.290)\end{array}$ \\
\hline $\operatorname{sgp}$ & $\begin{array}{c}0.042 \\
(0.028)\end{array}$ & $\begin{array}{c}0.047^{*} \\
(0.028)\end{array}$ & $\begin{array}{c}0.063^{* *} \\
(0.029)\end{array}$ & $\begin{array}{c}0.041 \\
(0.030)\end{array}$ & $\begin{array}{c}0.044 \\
(0.030)\end{array}$ & $\begin{array}{c}0.039 \\
(0.028)\end{array}$ \\
\hline trend & $\begin{array}{c}0.013^{* * *} \\
(0.004)\end{array}$ & $\begin{array}{c}0.014^{* * *} \\
(0.005)\end{array}$ & $\begin{array}{c}0.015^{* * *} \\
(0.005)\end{array}$ & $\begin{array}{c}0.012^{* *} \\
(0.005)\end{array}$ & $\begin{array}{c}0.013^{* * *} \\
(0.005)\end{array}$ & $\begin{array}{c}0.013^{\text {*** }} \\
(0.005)\end{array}$ \\
\hline$R^{2}$ & 0.702 & 0.636 & 0.647 & 0.654 & 0.642 & 0.735 \\
\hline
\end{tabular}

Notes: Specification according to model (d) in Table 3. Fixed effect estimation with standard errors robust to heteroskedasticity and autocorrelation (Newey-West).

Table 4: Determinants of fiscal rules II 


\begin{tabular}{|c|c|c|c|c|}
\hline \multirow{2}{*}{$\begin{array}{l}\text { Dependent Variable } \\
\text { Deficit/GDP }\end{array}$} & \multicolumn{2}{|c|}{ Fixed Effects } & \multirow{2}{*}{$\frac{\text { FE IV2SLS }}{(\mathrm{c})}$} & \multirow{2}{*}{$\begin{array}{c}\text { GMM } \\
\text { (d) }\end{array}$} \\
\hline & (a) & (b) & & \\
\hline $\begin{array}{l}\text { Tax autonomy } \\
\operatorname{tax}_{(t-1)}\end{array}$ & $\begin{array}{c}-0.013^{* *} \\
(0.006)\end{array}$ & & & \\
\hline $\operatorname{tax}_{(t-1)} *$ unitary & & $\begin{array}{c}0.015 \\
(0.011)\end{array}$ & $\begin{array}{c}0.038^{* *} \\
(0.017)\end{array}$ & $\begin{array}{c}0.009 \\
(0.010)\end{array}$ \\
\hline $\operatorname{tax}_{(t-1)} *$ federal & & $\begin{array}{c}-0.029^{* * *} \\
(0.008)\end{array}$ & $\begin{array}{c}-0.032^{* * *} \\
(0.010)\end{array}$ & $\begin{array}{c}-0.014^{* *} \\
(0.005)\end{array}$ \\
\hline $\begin{array}{l}\text { Fiscal rules } \\
\text { rules }\end{array}$ & $\begin{array}{l}-0.001 \\
(0.002)\end{array}$ & & & \\
\hline rules $*$ unitary & & $\begin{array}{c}-0.005^{* *} \\
(0.002)\end{array}$ & $\begin{array}{c}-0.013^{* * *} \\
(0.004)\end{array}$ & $\begin{array}{c}-0.003^{*} \\
(0.002)\end{array}$ \\
\hline rules $*$ federal & & $\begin{array}{l}0.001 \\
(0.003)\end{array}$ & $\begin{array}{c}0.000 \\
(0.003)\end{array}$ & $\begin{array}{c}0.001 \\
(0.001)\end{array}$ \\
\hline $\begin{array}{l}\text { Controls } \\
\text { def_cg_rev }\end{array}$ & $\begin{array}{l}0.007^{*} \\
(0.004)\end{array}$ & $\begin{array}{c}0.006 \\
(0.004)\end{array}$ & $\begin{array}{c}0.006 \\
(0.005)\end{array}$ & $\begin{array}{c}0.004 \\
(0.004)\end{array}$ \\
\hline edec & $\begin{array}{c}0.020^{* *} \\
(0.008)\end{array}$ & $\begin{array}{c}0.026^{* * *} \\
(0.008)\end{array}$ & $\begin{array}{c}0.024^{* *} \\
(0.011)\end{array}$ & $\begin{array}{c}0.016^{* *} \\
(0.008)\end{array}$ \\
\hline intexp_rev & $\begin{array}{l}-0.001 \\
(0.001)\end{array}$ & $\begin{array}{l}-0.000 \\
(0.001)\end{array}$ & $\begin{array}{l}0.000 \\
(0.001)\end{array}$ & $\begin{array}{l}-0.001 \\
(0.001)\end{array}$ \\
\hline outgap & $\begin{array}{c}-0.000^{* *} \\
(0.000)\end{array}$ & $\begin{array}{l}-0.000 \\
(0.000)\end{array}$ & $\begin{array}{l}-0.000 \\
(0.000)\end{array}$ & $\begin{array}{l}-0.000 \\
(0.000)\end{array}$ \\
\hline unempl & $\begin{array}{l}-0.016 \\
(0.019)\end{array}$ & $\begin{array}{l}-0.017 \\
(0.019)\end{array}$ & $\begin{array}{l}-0.025 \\
(0.021)\end{array}$ & $\begin{array}{l}-0.000 \\
(0.016)\end{array}$ \\
\hline$I_{\text {population }}$ & $\begin{array}{c}0.805^{* * *} \\
(0.252)\end{array}$ & $\begin{array}{c}1.071^{* * *} \\
(0.263)\end{array}$ & $\begin{array}{c}1.140^{* * *} \\
(0.284)\end{array}$ & $\begin{array}{c}0.687^{* * *} \\
(0.184)\end{array}$ \\
\hline depratio & $\begin{array}{c}-0.086^{* *} \\
(0.041)\end{array}$ & $\begin{array}{c}-0.090^{* *} \\
(0.041)\end{array}$ & $\begin{array}{l}-0.070^{*} \\
(0.042)\end{array}$ & $\begin{array}{l}-0.043 \\
(0.034)\end{array}$ \\
\hline trend & $\begin{array}{c}0.000 \\
(0.000)\end{array}$ & $\begin{array}{l}-0.000 \\
(0.000)\end{array}$ & $\begin{array}{l}0.001 \\
(0.001)\end{array}$ & $\begin{array}{l}-0.000 \\
(0.000)\end{array}$ \\
\hline$L D V$ & & & & $\begin{array}{c}0.362^{* * *} \\
(0.075)\end{array}$ \\
\hline individual/year FE & Yes/Yes & Yes/Yes & Yes/Yes & Yes/Yes \\
\hline$R^{2}$ & 0.232 & 0.267 & 0.113 & \\
\hline K-P Weak Id. F & & & 10.01 & \\
\hline Sargan/Hansen & & & 12.96 & 228 \\
\hline Sargan/Hansen p-value & & & 0.226 & 0.120 \\
\hline $\mathrm{AR}(1) \mathrm{p}$-value & & & & 0.003 \\
\hline $\mathrm{AR}(2) \mathrm{p}$-value & & & & 0.287 \\
\hline
\end{tabular}

Notes: All models include individual and year fixed effects. Models (a) and (b): fixed effect estimations with standard errors robust to heteroskedasticity and autocorrelation (Newey-West); Model (c): fixed effect two stage least square estimation. First stage regressions are presented in Table 10 of Appendix B. Current and lagged values of instruments used for both types of countries; Model (d) Difference-GMM dynamic panel data estimation with robust standard errors and transformation of forward orthogonal deviations. LDV is the lagged dependent variable. Exogenous instruments are the same as for model (c).

Table 5: Regressions of deficits 


\begin{tabular}{|c|c|c|c|c|}
\hline \multirow[t]{3}{*}{ Dependent Variable } & \multicolumn{2}{|c|}{ Deficit/Revenues } & \multicolumn{2}{|c|}{ Deficit per capita } \\
\hline & IV 2SLS & Dynamic GMM & IV 2SLS & Dynamic GMM \\
\hline & (a) & (b) & (c) & (d) \\
\hline \multicolumn{5}{|l|}{ Tax autonomy } \\
\hline $\operatorname{tax}_{(t-1)} *$ unitary & $\begin{array}{c}0.334^{* *} \\
(0.141)\end{array}$ & $\begin{array}{c}0.169 \\
(0.113)\end{array}$ & $\begin{array}{l}0.105^{*} \\
(0.055)\end{array}$ & $\begin{array}{c}0.027 \\
(0.035)\end{array}$ \\
\hline $\operatorname{tax}_{(t-1)} *$ federal & $\begin{array}{c}-0.289^{* * *} \\
(0.075)\end{array}$ & $\begin{array}{c}-0.174^{* * *} \\
(0.047)\end{array}$ & $\begin{array}{c}-0.075^{* * *} \\
(0.026)\end{array}$ & $\begin{array}{c}-0.026^{* *} \\
(0.013)\end{array}$ \\
\hline \multicolumn{5}{|l|}{ Fiscal rules } \\
\hline rules $*$ unitary & $\begin{array}{c}-0.102^{\text {*** }} \\
(0.031)\end{array}$ & $\begin{array}{c}-0.043^{* * *} \\
(0.017)\end{array}$ & $\begin{array}{c}-0.034^{* * *} \\
(0.012)\end{array}$ & $\begin{array}{l}-0.006 \\
(0.005)\end{array}$ \\
\hline rules $*$ federal & -0.002 & 0.004 & -0.002 & 0.002 \\
\hline \multirow{2}{*}{$\begin{array}{l}\text { full set of controls } \\
\text { individual/year FE }\end{array}$} & Yes & Yes & Yes & Yes \\
\hline & Yes/Yes & Yes/Yes & Yes/Yes & Yes/Yes \\
\hline$R^{2}$ & 0.147 & & 0.125 & \\
\hline K-P Weak Id. F & 10.01 & & 10.01 & \\
\hline Sargan/Hansen & 12.64 & 228 & 11.18 & 228 \\
\hline Sargan/Hansen J p-value & 0.245 & 0.120 & 0.344 & 0.120 \\
\hline $\operatorname{AR}(1) \mathrm{p}$-value & & 0.002 & & 0.003 \\
\hline $\operatorname{AR}(2) \mathrm{p}$-value & & 0.539 & & 0.223 \\
\hline$* * * \quad \begin{array}{r}\mathrm{F} \\
* 0\end{array}$ & $\begin{array}{l}\text { ust stand } \\
* * \mathrm{p}<0 \text {. }\end{array}$ & $\begin{array}{l}\text { errors in parer } \\
* \mathrm{p}<0.1, \mathrm{n}=24\end{array}$ & $\mathrm{~N}=19 \mathrm{~T}=$ & \\
\hline
\end{tabular}

Notes: Two stage least square estimations in (a) and (c) and Difference-GMM in (b) and (d). Set of control variables as before, results not reported here but in Table 9 of Appendix B.

Table 6: Alternative dependent variables 


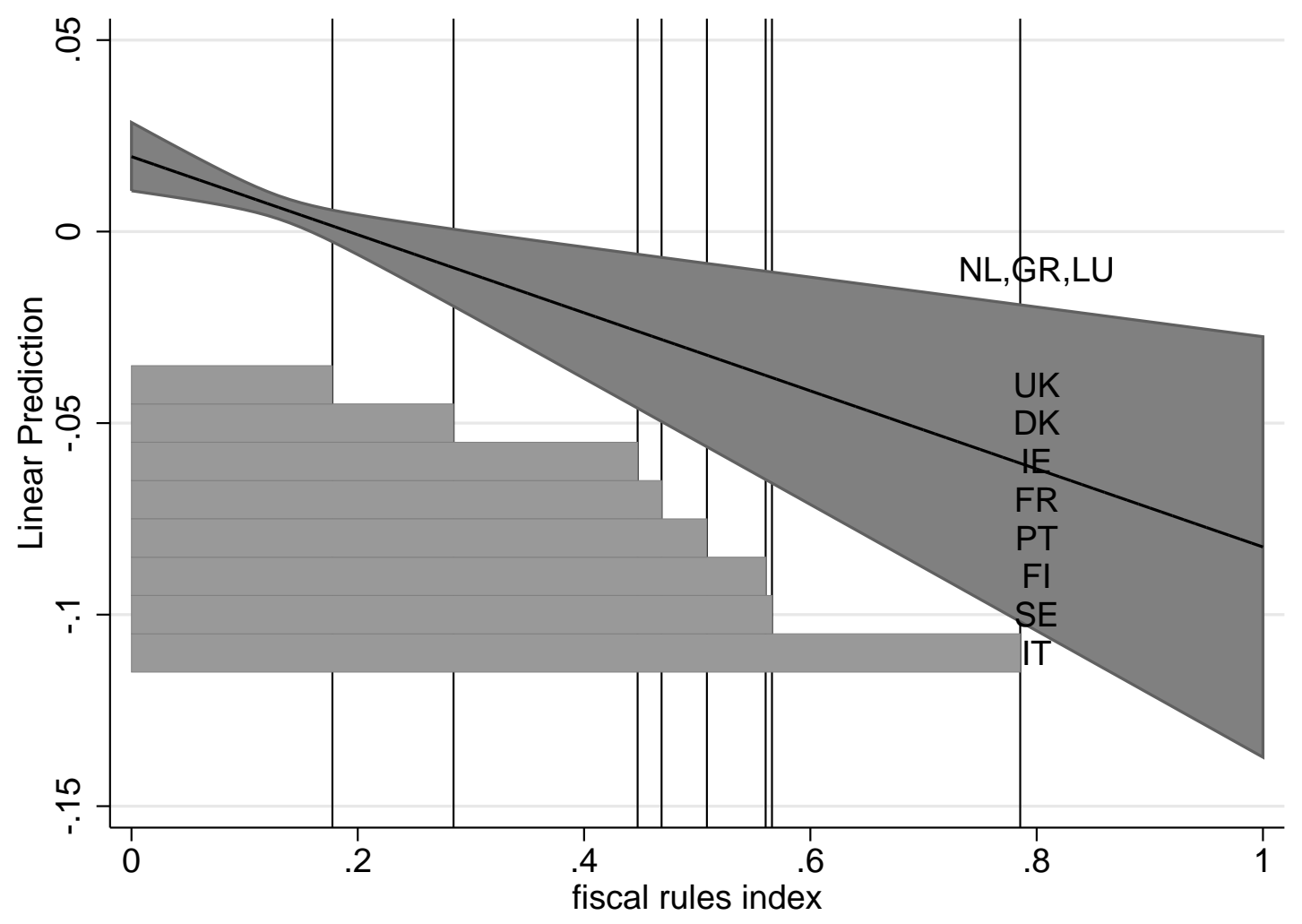

(a) Effect of fiscal rules in unitary countries

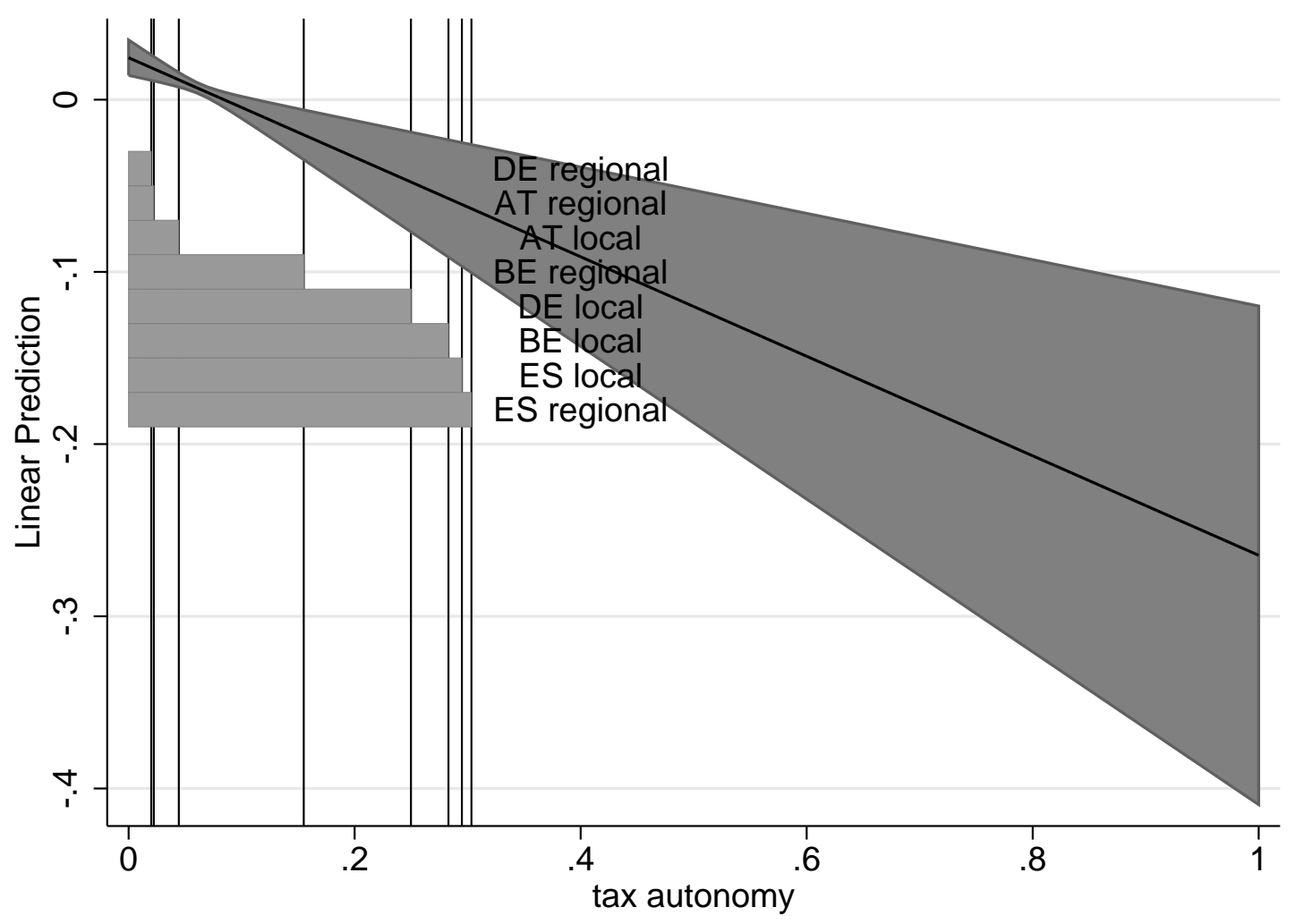

(b) Effect of tax autonomy in federations

Bars: (a) value of the rules index in 2008, (b) value of tax autonomy in 2008.

Figure 5: Policy implications 


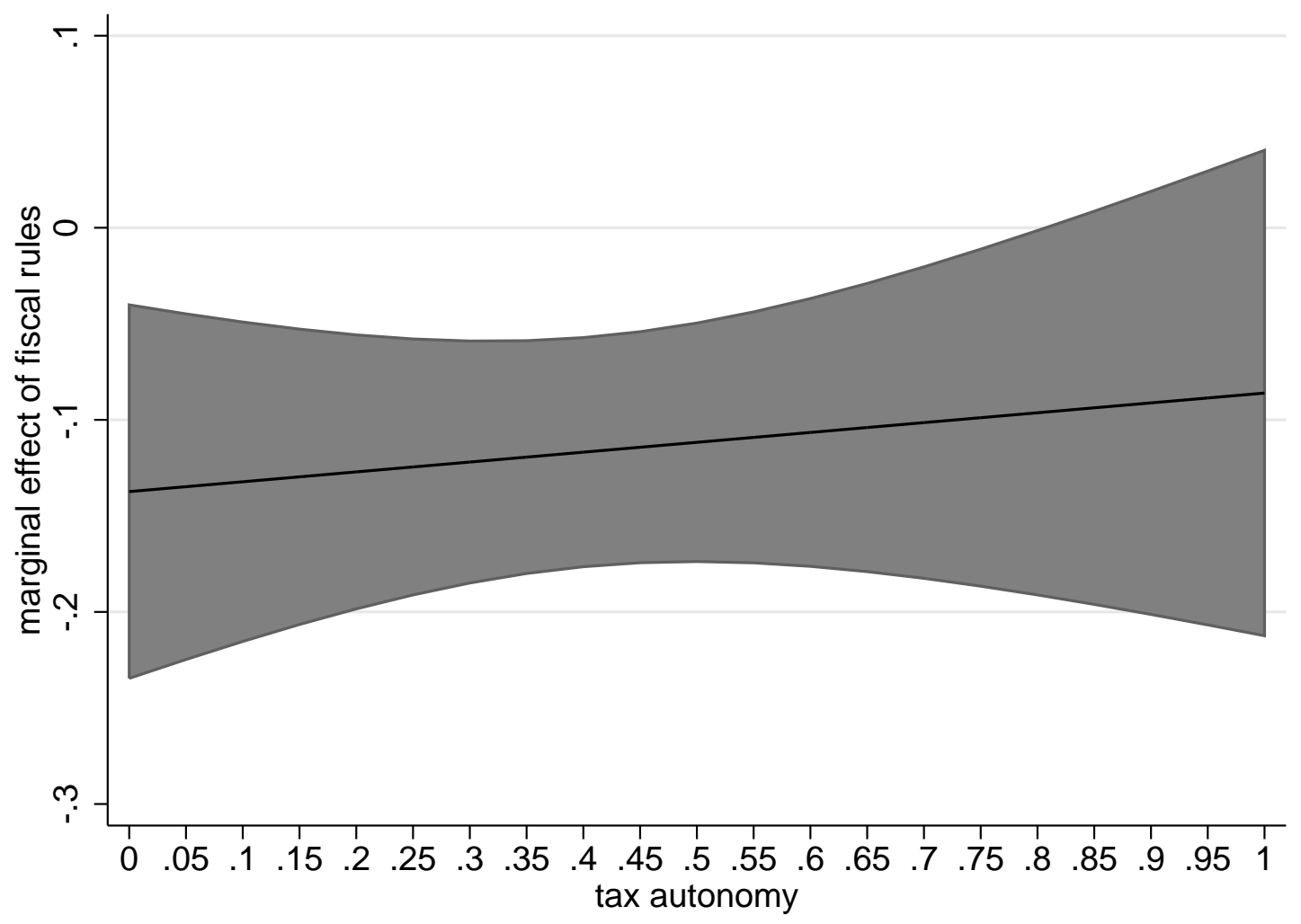

(a) Marginal interaction effect of fiscal rules in unitary countries

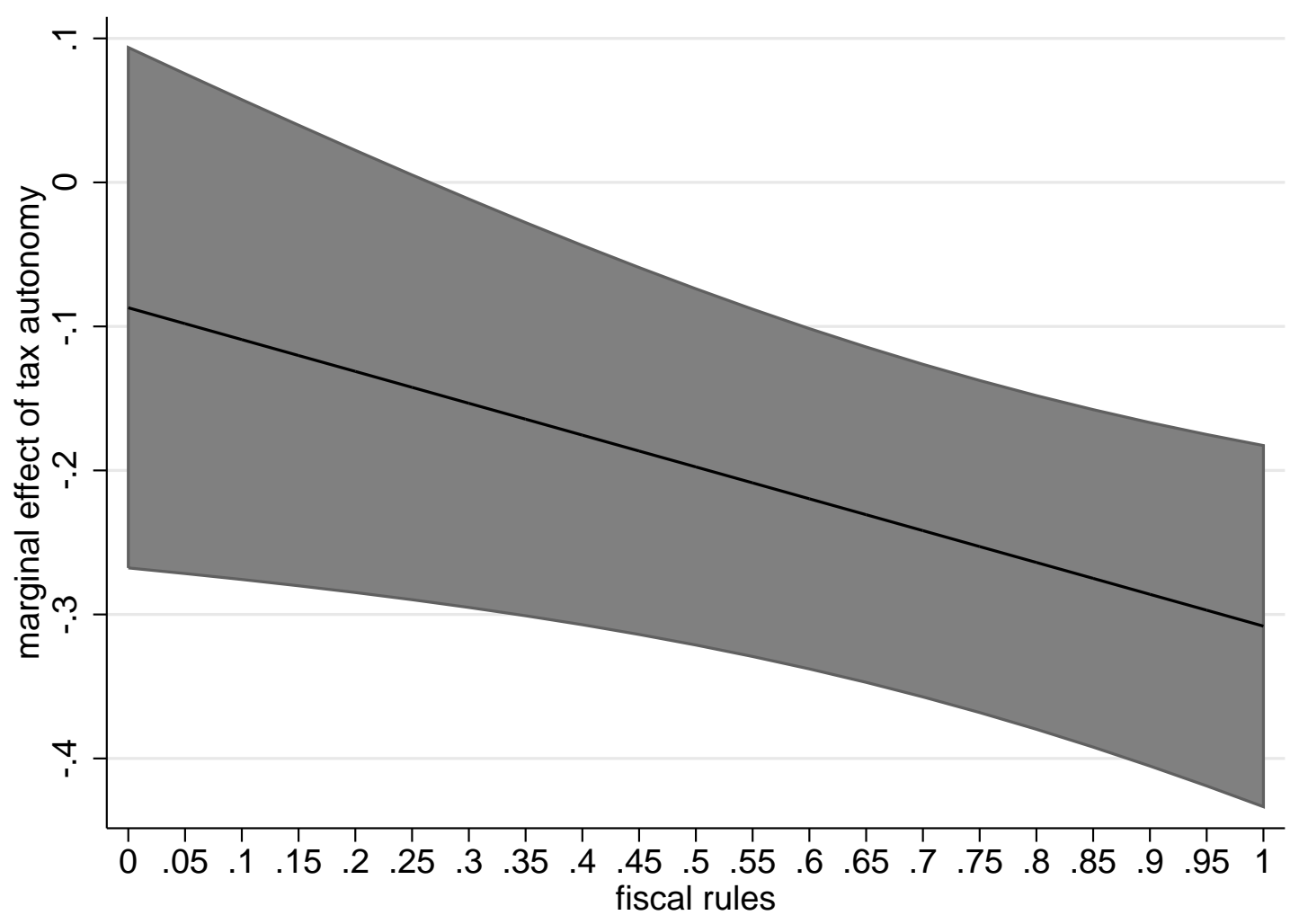

(b) Marginal interaction effect of tax autonomy in federations

Notes: (a) plot of the marginal effect of fiscal rules while allowing for interaction with tax autonomy, (b) plot of the marginal effect of tax autonomy while allowing for interaction with fiscal rules. 95\% CI in gray.

Figure 6: Marginal effects interaction terms 


\section{A. Federal classification}

The structure of European countries differs in many respects. One of the most important distinctions is the role and status of the sub-national sector due to the constitutional structure.

\begin{tabular}{l|l}
\hline federal countries & $\begin{array}{l}\text { Austria, Belgium, Germany, Spain } \\
\text { (local and regional levels included separately) }\end{array}$ \\
\hline unitary countries & $\begin{array}{l}\text { Denmark, Finland, France, Greece, Ireland, Italy, } \\
\text { Luxembourg, The Netherlands, Portugal, Sweden, United Kingdom } \\
\text { (consolidated sub-national values included) }\end{array}$ \\
\hline
\end{tabular}

Table 7: Unitary and federal classification

Three countries out of the EU15 are original federations as written down in the respective constitution (Austria, Belgium, Germany), and another country (Spain) has a very regionalized structure. All these countries have had handed over important responsibilities to the regional and local level, and these sub-national governments have significant own legislative powers. I treat this group of countries as federations in my analysis. The other group of states consists of unitary countries, but those may have a different number of sub-national levels. While Finland has only a local level sector, the remaining unitary countries (Denmark, France, Greece, Ireland, Italy, Luxembourg, the Netherlands, Portugal, Sweden, and the United Kingdom) have at least one regional level, but with limited legal autonomy, compared to their federal counterparts. As indicated in Table 7, I group all these countries as unitary ones. 


\section{B. Additional regression results}

\section{B.1. Results interaction model}

\begin{tabular}{|c|c|c|}
\hline \multirow[t]{3}{*}{ Dependent Variable } & \multicolumn{2}{|c|}{ Interaction Terms } \\
\hline & Deficit/GDP & Deficit/Revenues \\
\hline & (a) & (b) \\
\hline \multicolumn{3}{|l|}{ Unitary countries } \\
\hline $\operatorname{tax}_{(t-1)} *$ unitary & $\begin{array}{c}0.044^{* * *} \\
(0.015)\end{array}$ & $\begin{array}{c}0.380^{* *} \\
(0.156)\end{array}$ \\
\hline rules $*$ unitary & $\begin{array}{c}-0.019^{* * *} \\
(0.005)\end{array}$ & $\begin{array}{c}-0.137^{* *} \\
(0.050)\end{array}$ \\
\hline $\operatorname{rules} * \operatorname{tax}_{(t-1)} *$ unitary & $\begin{array}{c}0.010 \\
(0.009)\end{array}$ & $\begin{array}{c}0.051 \\
(0.096)\end{array}$ \\
\hline \multicolumn{3}{|l|}{ Federal countries } \\
\hline $\operatorname{tax}_{(t-1)} *$ federal & $\begin{array}{l}-0.005 \\
(0.012)\end{array}$ & $\begin{array}{l}-0.087 \\
(0.092)\end{array}$ \\
\hline rules $*$ federal & $\begin{array}{c}0.001 \\
(0.003)\end{array}$ & $\begin{array}{c}0.008 \\
(0.027)\end{array}$ \\
\hline $\operatorname{rules} * \operatorname{tax}_{(t-1)} *$ federal & $\begin{array}{c}-0.030^{* *} \\
(0.011)\end{array}$ & $\begin{array}{c}-0.221^{* *} \\
(0.096)\end{array}$ \\
\hline \multicolumn{3}{|l|}{ Controls } \\
\hline$d e f \_c g \_r e v$ & $\begin{array}{c}0.006 \\
(0.006)\end{array}$ & $\begin{array}{l}0.074^{*} \\
(0.042)\end{array}$ \\
\hline edec & $\begin{array}{c}0.020 \\
(0.013)\end{array}$ & $\begin{array}{l}0.181^{*} \\
(0.087)\end{array}$ \\
\hline intexp_rev & $\begin{array}{l}-0.000 \\
(0.001)\end{array}$ & $\begin{array}{c}0.002 \\
(0.008)\end{array}$ \\
\hline outgap & $\begin{array}{l}-0.000 \\
(0.000)\end{array}$ & $\begin{array}{l}-0.000 \\
(0.002)\end{array}$ \\
\hline unempl & $\begin{array}{l}-0.034^{*} \\
(0.019)\end{array}$ & $\begin{array}{l}-0.148 \\
(0.146)\end{array}$ \\
\hline$I_{\text {population }}$ & $\begin{array}{l}1.316^{* * *} \\
(0.283)\end{array}$ & $\begin{array}{c}11.074^{* * *} \\
(3.133)\end{array}$ \\
\hline depratio & $\begin{array}{c}-0.076^{* *} \\
(0.031)\end{array}$ & $\begin{array}{l}-0.511^{*} \\
(0.294)\end{array}$ \\
\hline trend & $\begin{array}{l}-0.000 \\
(0.000)\end{array}$ & $\begin{array}{l}-0.001 \\
(0.001)\end{array}$ \\
\hline Constant & $\begin{array}{c}-1.145^{* * *} \\
(0.258)\end{array}$ & $\begin{array}{c}-9.741^{* * *} \\
(2.818)\end{array}$ \\
\hline individual/year FE & Yes/Yes & Yes/Yes \\
\hline$R^{2}$ & 0.312 & 0.289 \\
\hline Number of code & 19 & 19 \\
\hline
\end{tabular}

Notes: Results for a regression allowing for interactions between rules and $\operatorname{tax}_{(t-1)}$. Marginal effects of model (b) presented in pictures 6 (a) and (b).

Table 8: Results interaction model 


\section{B.2. Details to Table 6}

\begin{tabular}{|c|c|c|c|c|}
\hline \multirow[t]{3}{*}{ Dependent Variable } & \multicolumn{2}{|c|}{ Deficit/Revenues } & \multicolumn{2}{|c|}{ Deficit per capita } \\
\hline & IV 2SLS & Dynamic GMM & IV 2SLS & Dynamic GMM \\
\hline & (a) & (b) & (c) & (d) \\
\hline \multicolumn{5}{|l|}{ Lag } \\
\hline LDV & & $\begin{array}{c}0.275^{* * *} \\
(0.077)\end{array}$ & & $\begin{array}{c}0.451^{* * *} \\
(0.070)\end{array}$ \\
\hline \multicolumn{5}{|l|}{ Controls } \\
\hline def_cg_rev & $\begin{array}{c}0.077^{* *} \\
(0.036)\end{array}$ & $\begin{array}{c}0.058^{*} \\
(0.032)\end{array}$ & $\begin{array}{c}0.021 \\
(0.014)\end{array}$ & $\begin{array}{c}0.010 \\
(0.012)\end{array}$ \\
\hline edec & $\begin{array}{c}0.201^{* *} \\
(0.088)\end{array}$ & $\begin{array}{c}0.152^{* *} \\
(0.061)\end{array}$ & $\begin{array}{c}0.071^{* *} \\
(0.034)\end{array}$ & $\begin{array}{l}0.039^{*} \\
(0.022)\end{array}$ \\
\hline intexp_rev & $\begin{array}{c}0.002 \\
(0.007)\end{array}$ & $\begin{array}{c}-0.004 \\
(0.006)\end{array}$ & $\begin{array}{c}0.001 \\
(0.003)\end{array}$ & $\begin{array}{l}-0.002 \\
(0.002)\end{array}$ \\
\hline outgap & $\begin{array}{c}0.000 \\
(0.002)\end{array}$ & $\begin{array}{l}-0.000 \\
(0.002)\end{array}$ & $\begin{array}{c}-0.001^{* *} \\
(0.001)\end{array}$ & $\begin{array}{c}-0.001^{* *} \\
(0.000)\end{array}$ \\
\hline unempl & $\begin{array}{l}-0.092 \\
(0.214)\end{array}$ & $\begin{array}{l}-0.000 \\
(0.161)\end{array}$ & $\begin{array}{c}-0.123^{*} \\
(0.066)\end{array}$ & $\begin{array}{l}-0.038 \\
(0.047)\end{array}$ \\
\hline$I_{\text {population }}$ & $\begin{array}{c}9.875^{* * *} \\
(3.040)\end{array}$ & $\begin{array}{c}6.869^{* * *} \\
(2.176)\end{array}$ & $\begin{array}{c}2.563^{* *} \\
(1.054)\end{array}$ & $\begin{array}{c}1.289^{* * *} \\
(0.500)\end{array}$ \\
\hline depratio & $\begin{array}{c}-0.481 \\
(0.359)\end{array}$ & $\begin{array}{c}-0.313 \\
(0.308)\end{array}$ & $\begin{array}{c}-0.213^{*} \\
(0.122)\end{array}$ & $\begin{array}{c}-0.109 \\
(0.082)\end{array}$ \\
\hline trend & $\begin{array}{c}0.006 \\
(0.007)\end{array}$ & $\begin{array}{l}-0.001 \\
(0.001)\end{array}$ & $\begin{array}{c}0.002 \\
(0.003)\end{array}$ & $\begin{array}{c}0.000 \\
(0.000)\end{array}$ \\
\hline (w) & bust sta & rd errors in pa & theses & \\
\hline
\end{tabular}

Notes: Table shows the results for control variables included in the estimations but not presented in the text in table 6 .

Table 9: Results of controls according to Table 6 


\begin{tabular}{|c|c|c|}
\hline \multirow[b]{2}{*}{ Equation: rules* } & \multicolumn{2}{|c|}{ Model (c) } \\
\hline & unitary & federal \\
\hline \multicolumn{3}{|l|}{ Instruments } \\
\hline contract $*$ unitary & $\begin{array}{l}-0.048 \\
(0.055)\end{array}$ & $\begin{array}{c}0.014 \\
(0.017)\end{array}$ \\
\hline $\operatorname{contract}_{(t-1)} *$ unitary & $\begin{array}{c}-0.168^{* *} \\
(0.083)\end{array}$ & $\begin{array}{c}0.020 \\
(0.014)\end{array}$ \\
\hline contract $*$ federal & $\begin{array}{c}0.025 \\
(0.029)\end{array}$ & $\begin{array}{c}-0.349^{* * *} \\
(0.067)\end{array}$ \\
\hline $\operatorname{contract}_{(t-1)} *$ federal & $\begin{array}{c}0.089 * * * \\
(0.030)\end{array}$ & $\begin{array}{c}-0.041^{* * *} \\
(0.014)\end{array}$ \\
\hline district $*$ unitary & $\begin{array}{l}0.006^{*} \\
(0.004)\end{array}$ & $\begin{array}{c}0.001 \\
(0.001)\end{array}$ \\
\hline $\operatorname{district~}_{(t-1)} *$ unitary & $\begin{array}{c}0.012^{* * *} \\
(0.002)\end{array}$ & $\begin{array}{l}-0.000 \\
(0.000)\end{array}$ \\
\hline district $*$ federal & $\begin{array}{l}-0.006 \\
(0.004)\end{array}$ & $\begin{array}{c}0.009^{* *} \\
(0.004)\end{array}$ \\
\hline $\operatorname{district~}_{(t-1)} *$ federal & $\begin{array}{l}0.008^{*} \\
(0.004)\end{array}$ & $\begin{array}{l}-0.002 \\
(0.003)\end{array}$ \\
\hline herfgov * unitary & $\begin{array}{l}-0.199 \\
(0.137)\end{array}$ & $\begin{array}{c}0.034 \\
(0.036)\end{array}$ \\
\hline $\operatorname{herfgov}_{(t-1)} *$ unitary & $\begin{array}{c}-0.434^{* *} \\
(0.174)\end{array}$ & $\begin{array}{l}-0.020 \\
(0.031)\end{array}$ \\
\hline herfgov $*$ federal & $\begin{array}{l}-0.131 \\
(0.090)\end{array}$ & $\begin{array}{c}0.053 \\
(0.049)\end{array}$ \\
\hline $\operatorname{herfgov}_{(t-1)} *$ federal & $\begin{array}{l}-0.017 \\
(0.077)\end{array}$ & $\begin{array}{c}0.199 * * * \\
(0.064)\end{array}$ \\
\hline \multicolumn{3}{|l|}{ Other variables } \\
\hline $\operatorname{tax}_{(t-1)} *$ unitary & $\begin{array}{c}1.649^{* * *} \\
(0.475)\end{array}$ & $\begin{array}{l}-0.020 \\
(0.084)\end{array}$ \\
\hline $\operatorname{tax}_{(t-1)} *$ federal & $\begin{array}{c}-0.419^{* *} \\
(0.189)\end{array}$ & $\begin{array}{c}1.434^{* * *} \\
(0.135)\end{array}$ \\
\hline$d e f \_c g \_r e v$ & $\begin{array}{l}-0.072 \\
(0.125)\end{array}$ & $\begin{array}{c}0.013 \\
(0.036)\end{array}$ \\
\hline edec & $\begin{array}{l}-0.534^{*} \\
(0.276)\end{array}$ & $\begin{array}{c}0.094 \\
(0.095)\end{array}$ \\
\hline intexp_rev & $\begin{array}{c}0.003 \\
(0.031)\end{array}$ & $\begin{array}{c}0.008 \\
(0.011)\end{array}$ \\
\hline outgap & $\begin{array}{c}0.003 \\
(0.006)\end{array}$ & $\begin{array}{c}0.000 \\
(0.002)\end{array}$ \\
\hline unempl & $\begin{array}{l}-0.419 \\
(0.888)\end{array}$ & $\begin{array}{l}-0.115 \\
(0.196)\end{array}$ \\
\hline$I_{\text {population }}$ & $\begin{array}{c}3.934 \\
(8.941)\end{array}$ & $\begin{array}{c}2.780 \\
(4.428)\end{array}$ \\
\hline depratio & $\begin{array}{l}3.814^{* *} \\
(1.854)\end{array}$ & $\begin{array}{c}0.303 \\
(0.508)\end{array}$ \\
\hline trend & $\begin{array}{l}-0.001 \\
(0.021)\end{array}$ & $\begin{array}{c}0.002 \\
(0.007)\end{array}$ \\
\hline$R^{2}$ & 0.608 & 0.763 \\
\hline $\begin{array}{l}\text { Robust standard e } \\
\quad * * * \mathrm{p}<0.01, * *\end{array}$ & $\begin{array}{l}\text { rs in pare } \\
0.05, * \mathrm{p}\end{array}$ & $\begin{array}{l}\text { theses } \\
0.1\end{array}$ \\
\hline
\end{tabular}

Notes: First stage regressions for the results presented in table 6 . The endogenous variable in the second stage is the fiscal rules index for both types of government.

Table 10: First stage regressions to Table 6 


\section{Construction of the rules index}

The construction of the rules index follows the European Commission (2009). I adopt their data-set and calculate the rules index for the sub-national sectors. The data used for the computation of the fiscal rules index is based on a data-set provided by the European Commission. All information is public and available online. All balanced budget rules and debt rules applying to the sub-national sector are taken into account. All information about the included rules are available on the web-page of the European Commission at http://ec.europa.eu/economy_finance/db_indicators/fiscal_governance/fiscal_ rules/index_en.htm. Rules applying to the general government sector are weighted by the respective sub-national expenditure share in it. The indicator is the sum of each criterion, divided by the total number of criteria. Each criteria itself is divided by the maximum score, i.e. all variables are forced to be between zero and one. If more than one rule applies, the rule index is the sum of the individual values. Finally the indicator is denominated by the maximum value in the sample, i.e. forced to vary between 0 and 1 .

- Criterion 1: statutory base of the rule

The score of this criterion index is constructed as a simple average of the two elements below:

- Criterion 1a: Statutory or legal base of the rule

4 is assigned for a constitutional base

3 if the rule is based on a legal act (e.g. Public finance Act, Fiscal Responsibility Law)

2 if the rule is based on a coalition agreement or an agreement reached by different general government tiers (and not enshrined in a legal act)

1 for political commitment by a given authority (central or local government, Minister of Finance)

- Criterion 1b: Room for setting or revising objectives

3 if there is no margin for adjusting objectives (they are encapsulated in the document underpinning the rule)

2 there is some but constrained margin in setting or adjusting objectives

1 there is complete freedom in setting objectives (the statutory base of the rule merely contains broad principles or the obligation for the government or the relevant authority to set targets)

- Criterion 2: Nature of the body in charge of monitoring respect of the rule

The score of this variable is augmented by one point in case there is a real time monitoring of compliance with the rule (e.g. existence of alert mechanisms in case there is a risk of non-respect of the rule).

3 if there is a monitoring by an independent authority (Fiscal Council, Court of Auditors or any other Court) or the national Parliament 
2 monitoring by the Ministry of Finance or any other government body

1 no regular public monitoring of the rule (there is no report systematically assessing compliance)

- Criterion 3: Nature of the body in charge of enforcement of the rule

3 enforcement by an independent authority (Fiscal Council or any Court) or the National Parliament

2 enforcement by the Ministry of Finance or any other government body

1 no specific body in charge of enforcement

- Criterion 4: Enforcement mechanisms of the rule

The score of this variable is augmented by 1 point in case escape clauses are foreseen and clearly specified.

4 there are automatic correction and sanction mechanisms in case of non-compliance

3 there is an automatic correction mechanism in case of non-compliance and the possibility of imposing sanctions

2 the authority responsible is obliged to take corrective measures in case of non-compliance or is obliged to present corrective proposals to Parliament or the relevant authority

1 there is no ex-ante defined actions in case of non-compliance

- Criterion 5: Media visibility of the rule

3 is assigned if the rule observance is closely monitored by the media, and if non-compliance is likely to trigger a public debate

2 for high media interest in rule-compliance, but non-compliance is unlikely to invoke a public debate

1 for no or modest interest of the media

\section{Robustness check: federal specification}

Throughout the text I used two different data points for each federal country, i.e. I included the local and regional level as separate observations. Table 11 shows the results of two robustness checks in order to proof whether results remain unchanged when the data is treated differently. Model (a) repeats the previous results of model (d) in table 5 for comparison.

The next column shows a regression where I merged the local and regional government in the four federal countries. Instead of 19 observations per year the data-set now consists out of 15, one for each included country. However, results remain unchanged and the main conclusions are as before.

As a last check, I estimate different coefficients for the local and regional level in federations. That means that $\boldsymbol{\Phi}$ now becomes the following:

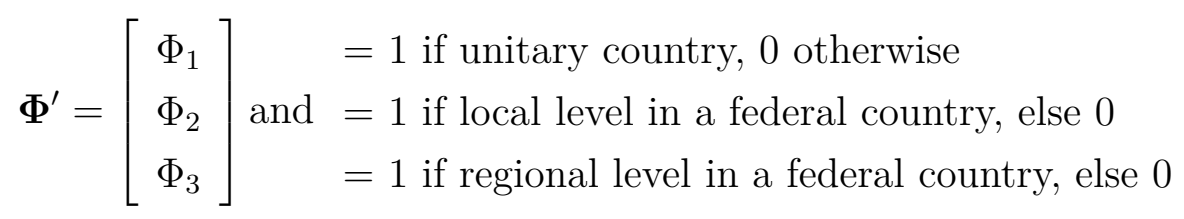


However, results (c) are in line with the previous findings. The signs and magnitude of coefficients for $\operatorname{tax}_{(t-1)}$ are similar for the local and regional level. Rules remain insignificant in both cases. 


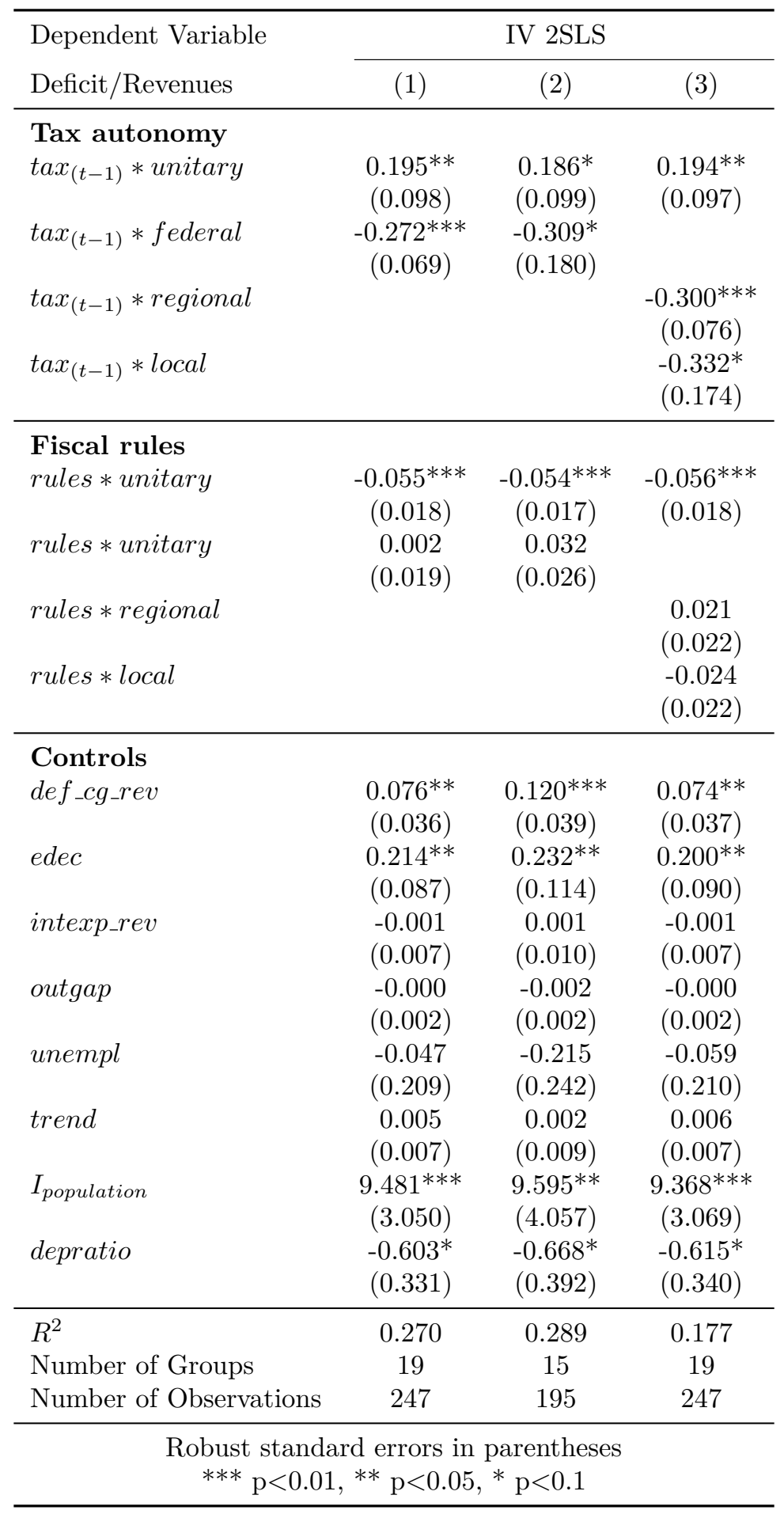

Notes: Model (a): repetition of the estimation of model (d) in table 5 for comparison; Model (b): the local and regional level in federal countries are merged; Model (c): individual coefficients for the regional and local level in federal countries. All standard errors are robust to heteroskedasticity and autocorrelation (Newey-West).

Table 11: Separate coefficients for local and regional governments 